\title{
Hazai példák \\ a mentális térképezés alkalmazására
}

(Válogatás Bíró A. Zoltán, Csernák Boldizsár, Garamhegyi Ábel, Letenyei László és munkatársaik munkáiból)

A következó oldalakon néhány hazai példát mutatunk be a települések mentális térképének szerkesztésére. Ez a válogatás azért született, hogy bemutassa a mentális térképek hazai kutatásainak nagyrészt publikálatlan eredményeit. A válogatás a mentális térképezés módszertani sokszínúségének bemutatására törekszik. Jelen kötetben a kulturális antropológia, a szociológia, a térképészet és az alkalmazott településkutatás területeiról egyaránt választottunk példákat.

A csíkszeredai Kommunikációs Antropológia Munkacsoport nyolcvanas évekbeli kutatása antropológiai szemlélete és a résztvevó megfigyelésen alapuló strukturálatlan adatgyúijtése miatt lett válogatásunk elsó tanulmánya. A késóbbi hazai kutatásokban egyre inkább a strukturált jelleg lesz jellemzó. Az alkalmazott településfejlesztési célú kutatások már csak a szúkös idóbeni és anyagi korlátok miatt is az adatfelvétel standardizálásával kísérleteznek. Csernák Boldizsár és Garamhegyi Ábel kutatásaiban megjelennek a kvantitatív adatgyújtési és statisztikai adatfeldolgozási technikák.

A tanulmányok mentális térképekre vonatkozó részleteit - a szerzókkel egyeztetve rövidítve, kisebb módosításokkal, szemelvényekben tesszük közzé. A kihagyott mondatok helyét nem jelöljük.

A bemutatott tanulmányok listája:

Bíró A. Zoltán és a Kommunikációs Antropológia Munkacsoport tagjai 1991: Mentális környezet

Letenyei László 1993: Falusi társadalom rejtett kapcsolatai

Letenyei László 1997: Kószeg mentális térképe és ingatlantérképe

Csernák Boldizsár 2002: Befogadóállomásokon éló menekültek helyismerete és térhasználati szokásai

Letenyei László 2002: Eger mentális térképe

Garamhegyi Ábel 2001: Mentális térképek: egy holland példa

Letenyei László, Babarczi Annamária Marica és Lengyel Linda Márta 2003: Cece község mentális térképe

Letenyei László, Kovács Bence és Szathmári Milán 2004: Telki mentális térképe 


\section{Kommunikációs Antropológia Munkacsoport 1991: Mentális környezet*}

A Munkacsoport 1979-ben a romániai pártállam keretei közt informálisan jött létre. Az alábbiakban röviden bemutatott kutatást a nyolcvanas évek végén végezték, és '89-ben kéziratos formában tették közzé; a szöveget a magyarországi kiadásból vettük át. Innentól az eredeti szöveg részletei olvashatók.

A beépített térben való mozgás vizsgálata sajátos határterületet képez a mentális térképek, illetóleg a mindennapi kommunikatív viselkedés elemzése között. A Korondon (Hargita megye) végzett terepmunkán alapuló esettanulmány e kétféle elemzési szempont egységesítésével próbálkozik.

A vizsgálat számára egy olyan eseményt választottunk, amely a falu minden lakója számára ma is esemény: egy elhalálozást. Maga az esemény úgymond már jóval a haláleset elótt megkezdódik, amennyiben az illetó nagyon idós vagy beteg, és a haláleset után még sokáig tart, amíg „elenyészik”. Ugyanez a felerósödés, majd eltúnés mutatható ki akkor is, ha azt nézzük, hogy kinek milyen mértékben és kinek mennyi ideig esemény az esemény. Nyilvánvalóan a rokonok, szomszédok számára a legintenzívebb, a falu másik felén lakó család számára talán csak az alatt a három nap alatt jelentkezik, amíg a ceremónia lejátszódik.

A vizsgálat számára kiválasztott család nem áll a nyilvánosság elótt is „eljátszandó" kapcsolatban az elhunyt családjával. Nem kell részt vennie a temetésen, nem megy virrasztóba, nem szomszéd, nem ismerós, nem volt gazdasági vagy más természetú, kölcsönös vagy egyoldalú kötelezettsége, nem lakik a temetés útvonalán. Tevékenységüket vizsgálva azonban számos érdekes dologra figyelhetünk fel.

A család a megszokott munkáját végzi. Délelốtt fél tizenegy van, harangszó hallatszik. $\bar{A}$ szólal meg:

- „Húzzák a gyúló́t.”

Csend következik, mindenki tudja, hogy a temetési szertartásra hívja a harangszó a falusiakat. Tudják, hogy itt temetnek, s azt is, hogy abban a családban mi és hogyan változott meg a haláleset kapcsán. Részletes elképzelésük van arról is, hogy most éppen hogyan néz ki az udvar, hogyan rendezódnek el az udvaron, a házban és a kapu elótt a résztvevók, kik végzik el a kiszolgálást és más feladatokat. Ebból a háttérból kiindulva fogalmazódnak meg az elkövetkezó fél óra folyamatos szöveggé össze nem álló kijelentései:

* In: JANUS, 1991. ósz, Mentális környezet: 33-40. A Csíkszeredai Kommunikációs Antropológia Munkacsoport tagjai: Bíró A. Zoltán, Bodó Julianna, Gagyi József, Magyari Nándor László, Magyari-Vincze Enikó, Oláh Sándor. 
„Ott se lesz kevés koszorú!

Rusnya idót fogtak ki, eláznak.

Ejsze kitisztul...

Nem úgy néz ki...

Jó sár lesz béfelé!"

A beszélgetés a harangszó újabb megkondulásakor más fordulatot vesz. Ismét $\bar{A}$ szólal meg:

- „Na elindultak vele!”

Az ezután következó fél órát a folyamatos harangszó, valamint a temetési menetben való „képzelt részvétel” hangulata tölti ki. Kevés szó esik, azok is többnyire utalások, félmondatok, esetleg egy-egy rövidebb kérdés és válasz:

„Nem kell olyan messzire menni.

A Gózmalomnál lehetnek.

Vaj a Tómezei eltérónél.

A sógora hazajött-e?

Haza. Táviratoztak neki.

Eddig a fordulóban vannak...

- Na, kiértek!"

Az utolsó megjegyzés a harangszó elhalkulásakor hangzik el.

A történés maga az, hogy a falu lakói közül valakik körülbelül fél óra alatt megtesznek egy útszakaszt. Érdekes, hogy akik nem lehetnek jelen a menetben, azok is szükségét érzik annak, hogy mindennapi munkájuk automatikus végzése közben képzeletben ók is bejárják ezt az utat. Ezt a falu tereiról alkotott „mentális térképek” teszik lehetóvé.

A mentális térkép Korond valóságos térképétól lényegesen különbözik. Úgy juthatunk hozzá, hogy az elớzóhöz hasonló beszélgetések mellett megfigyeljük, hogy például az utcára küldött gyereknek milyen azonosító térelemeket sorolnak fel, vagy több embert felkérünk az adott útvonal megmagyarázására. Így összeáll az a közös mentális térkép, amely végsó soron a falu közös tudásának egy szeletét jelenti. 


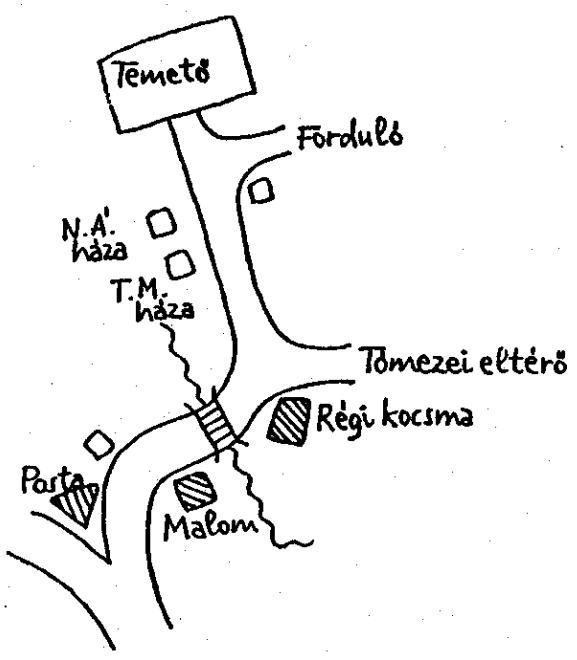

Korond mentális térképe
Az útvonal egyenes része alaposan lerövidült, a porták nagy része eltúnt, csak az a pár darab maradt meg, amely vagy különleges formája miatt, vagy a benne lakó család (tagok) valamilyen tulajdonságai miatt (jómódú ember, történt vele valami, közismert dolgot cselekedett, köztiszteletben áll) közös viszonyulási pontként szerepel. Hangsúlyosan említódnek az útelágazások, valamint az olyan közérdekú épületek, mint a Posta, a Gózmalom, a Korcsma.

Az utóbbi egy-két évtizedben ezeknek a kiemelt fontosságú épületeknek a funkciója megváltozott, a mentális térképen azonban változatlanul órzik hajdani identitásukat.

\section{Letenyei László 1993:}

\section{Falusi társadalom rejtett kapcsolatai*}

1992 és 1995 között több egyetem hallgatóinak részvételével folyt egy interdiszciplináris "falukutatás” Szatmár térségében, a magyar, ukrán és román határ mindhárom oldalán. Tanulmányaikat a hallgatók TDK-dolgozatként, majd önálló kötetben jelentették meg. E kötet "Falusi társadalom rejtett kapcsolatai" címú fejezetéból mutatjuk be a határ romániai oldalán fekvó Gencs község mentális térképére vonatkozó részt.

A kutatás központi kérdése az volt, hogy milyen falurészekben gondolkodnak Gencs lakói, és a különbözó falurészekhez tartozásból fakadó identitás befolyásolja-e, és ha igen, miként a társas kapcsolataikat és gazdasági viselkedésüket.

* TDK-dolgozat, késóbb átszerkesztve megjelent: Borsos Endre, Csite András és Letenyei László (szerk.) 1999: Rendszerváltozás utân. Falusi sorsforduló a Kárpát-medencében. Budapest: MTA PTI és SZÁMALK kiadó. Köszönet a gencsi lakosoknak, továbbá munkatársaimnak: Borsos Endrének, Csite Andrásnak, György Istvánnak, Kovács Róbertnek és másoknak. 
A kutatás adatgyújtési módszere a mentális térkép rajzoltatás volt. A kutatók arra kérték a település különbözó részein éló embereket, hogy vázolják fel egy üres papirlapra a település térképét, és azon jelöljék be különbözó falurészeket, valamint a törésvonalakat, tájékozódási pontokat, fó útvonalakat, csomópontokat. A térképrajzoltatást interjúsorozat illetve kérdóives adatfelvétel egészítette ki. A falurészek megitélését mindegyik adatgyújtési technika alkalmazása során folyamatosan jegyezték.

A bemutatott térkép a kutatók mentális térképét tükrözi a térképrajzoltatás, az interjūk és a kérdóiv adatainak feldolgozása alapján. A térképek feldolgozáshoz nem használtak számitógépes módszereket. A továbbiakban a szerzók szövege olvasható, rövidített és szerkesztett formában.

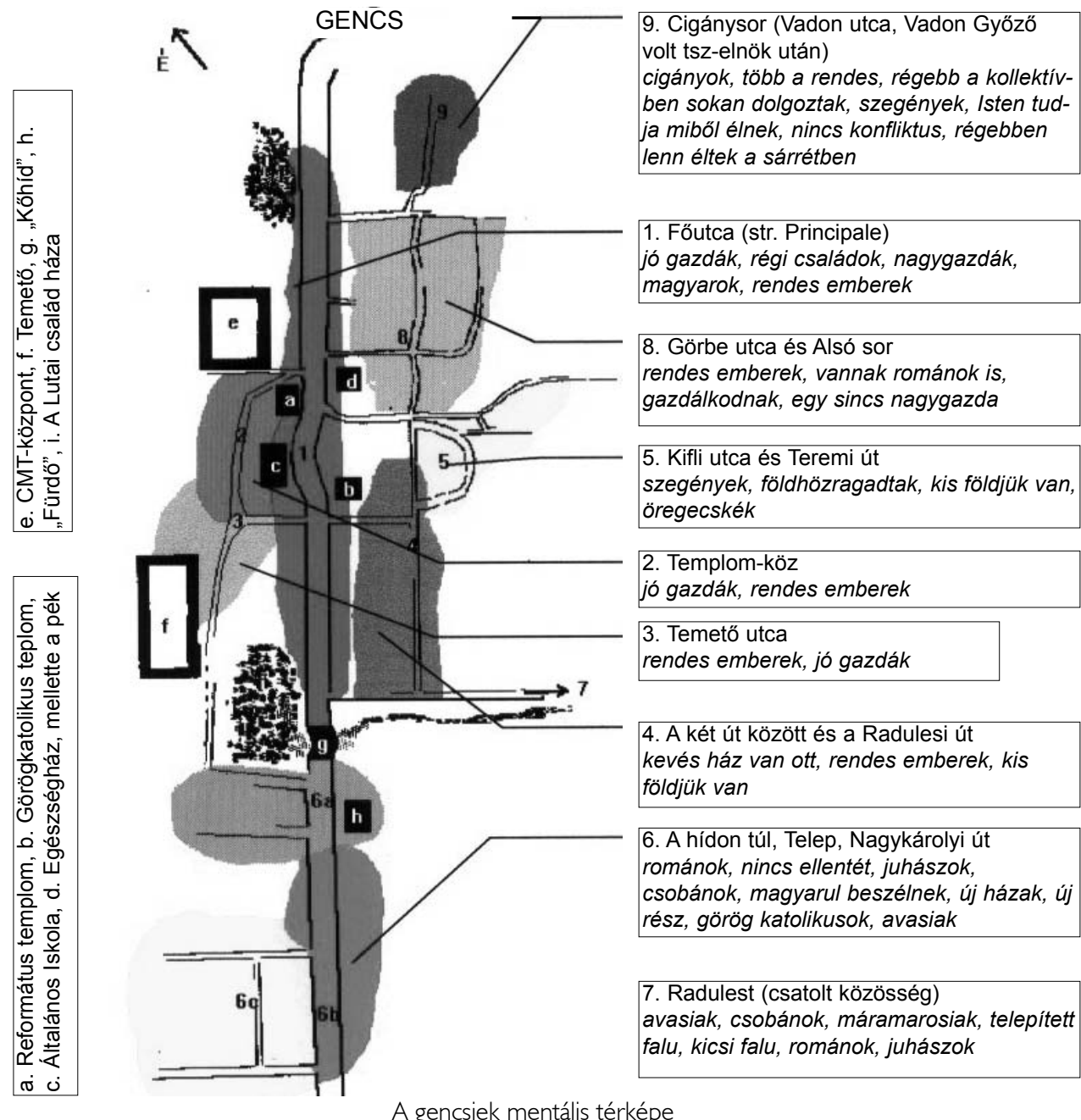

A gencsiek mentális térképe 
Terepmunkánkon Gencsen eleinte meglehetósen nehezünkre esett a tájékozódás. Nem kicsi a település, s a fóútról nyíló utcák meglehetósen egyformának túntek. Egy barátunk segítségképpen térképvázlatot rajzolt nekünk, feltüntetve rajta az utcákat, elágazásokat, fontosabb tájékozódási pontokat.

Nem sokkal késóbb sikerült megszereznünk a falu kisléptékú térképét is, egy rendezési tervvel együtt. Egybevetve a kettót, a különbség szembeszökó volt. A kézzel rajzolt térkép arányaiban jelentôsen eltért a valóságostól: a fontosnak tartott részek megnóttek, a kevésbé fontosak elmosódtak vagy eltúntek. A kognitív elhatárolások a rajzon úgy jelentek meg, mint valódi határok, gyakran átlépve a tényleges földrajzi határokon, vagy éppen megerósítve azokat.

A mentális térkép megragadhatósága ettól a pillanattól fogva kiemelten foglalkoztatott bennünket. A terepmunkánk során, beszélgetések közben figyeltünk fel arra, hogy az egyes mentális terek „szelleme”, azaz jellege a falusiak szerint mennyire fontos információ. Ezt a tudást igyekeztek velünk az ismerkedés utáni elsó pillanatokban megosztani, mintegy megóvandó minket attól, hogy bizonyos negyedekbe betévedjünk, vagy higgyünk azoknak, akik ebben és ebben az utcában laknak.

Hogy ezek a terek valóban releváns kategóriák, az mutatta meg, hogy a Gencsen e témában készített interjúk során egymással összecsengó információkat kaptunk. A terek elhatárolódása pontos, kivétel csupán a Telep (6.) (lásd késóbb). Fehér foltok egyáltalán nincsenek. A megkérdezetteknek mindig volt véleménye az egyes részek „szelleméról” is, azaz ismerték a hozzájuk fúzódó sztereotípiákat, igaz, ezt nem feltétlenül osztották. Jellemzóen tagadták azokat a negatív elóítéleteket, melyek a saját utcájukra, falurészükre vonatkoztak. Megismertük a Vadon utca (Strada Vadon), azaz a Cigánytelep (9.) történetét: Vadon Gyózó volt téeszelnökról kapta a nevét, aki kijárta a területet a cigányok számára.

A sztereotípiák gyújtésénél egyszerú szabályt követtünk: feljegyeztük, hogy mi hangzik el leggyakrabban a falurésszel kapcsolatban. Ez az eljárás egy csapdahelyzetet rejtett magában: a gyújtött jellemzések a megkülönböztetó vonásokat tartalmazzák, az azonosakat nem. Így például míg az adatközló fontosnak tartotta megjegyezni egy utcáról, hogy ott jórészt szegény emberek élnek (szemben a falu többi részével, vagy épp az ó utcájával), addig nem említette meg azt, hogy reformátusok az utca lakói, hiszen a református községben ez természetes. Gencsen kiemelték, ha egy utcában románok (is) laktak, de nem beszéltek a nemzetiségról, ha a lakosok mind magyarok voltak, hiszen ezt természetesnek tartották. Ilyen módon a ki nem mondott információknak is jelentósége van. 
Feltúnt, hogy bizonyos részeket szinte ugyanazokkal a tulajdonságokkal jellemeznek a helybeliek. Ilyen például Gencsen a Templom-köz és a Temetó utca, ahol mindkettóról olyan adatokat kaptunk, hogy az ott élók rendes emberek, jó gazdák. (Hozzá hallhatjuk még azokat a ki nem mondott információkat, hogy magyarok és reformátusok, hiszen mondanák, ha ez nem így lenne.)

Miért tekintik a helybeliek két térnek ezt a két szomszédos, hasonló megítélésú utcát? A kérdés megválaszolására a kapcsolatháló-elemzést hívtuk segítségül.

A kérdóív adatai és a kiegészító adatok alapján a háztartások kapcsolataira vonatkozó adatokat a falurészek szerint összegeztük.

Összehasonlítva az egyes részeken belüli és az azokon túlmutató kapcsolatokat azt a megállapítást tehettük, hogy a részeken belüli (belsó) kapcsolatok Gencsen minden esetben szignifikánsan erósebbek voltak az azokon túlmutató (külsó) kapcsolatoknál.

Ez ad választ az imént feltett kérdésre, azaz, hogy miért tartanak a falubeliek két különbözó térnek olyan, fóbb tulajdonságaiban hasonlónak tartott utcát, mint a Templom és a Temetó utcája Gencsen. Azért, mert az egyes utcákon belül olyan, egymáshoz sok szállal szorosan kapcsolódó háztartások vannak, amelyek belsó kapcsolódása sokkal erósebb az utcán túlmutató (külsó) kapcsolódásaikon.

A következó gráf Gencs mentális tereinek egymáshoz való kapcsolódásait ábrázolja. A ritkán elóforduló (15\% alatti) kapcsolatokat nem vettük figyelembe. A gráfból többféle információ is leolvasható. Az irány a gazdasági kapcsolatok
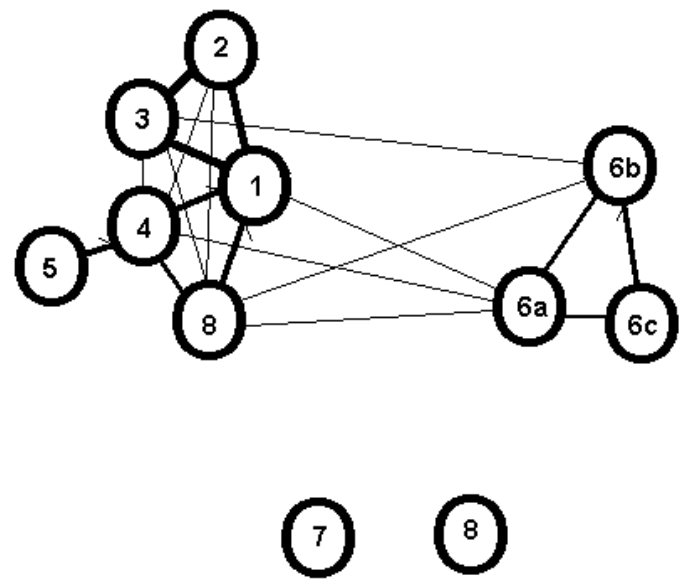

A gencsi falurészek lakói közötti

társadalmi kapcsolatok gráfja irányát jelöli. A négyféle vastagságú vonal azt jelenti, hogy a négyféle vizsgált kapcsolat (rokoni, baráti, gazdasági és civil szervezeti) közül hány köti össze a vizsgált részek lakóit. Nem súlyoztuk az adatokat aszerint, hogy milyen gyakran fordulnak eló. A pontok fizikai helye egy gráfon általában nem hordoz információt, itt viszont a falurészek mentális távolságát hivatott érzékeltetni. 
A gráfról a gencsi társadalmon belüli két csoport éles elhatárolódása olvasható le. Ez részben a családi koalíciók társadalomszervezó erejéról tanúskodik, részben pedig a két mentális tér közötti távolságot mutatja. Gencsen két családi koalíció van. A református gazda családok többnyire 30-100 holdas birtokkal rendelkeztek a téeszesítés elótt. A kommunista rendszerben vagy a háttérbe szorultak, vagy értelmiségiként kerültek vissza a falu elitjébe. Az „ellenpárt” azokat a korábban csak kevés földdel rendelkezó görög katolikus családokat tömöríti, amelyek elegendó tókét halmoztak fel ahhoz, hogy mára a gazdasági elit részeivé váljanak, és versenyt támasszanak a „régi” elitnek.

A két nagy csoportot (a 6., „a hídon túl”, versus az összes többi) tulajdonképpen a helyi román és magyar társadalomnak feleltették meg.

Az eredmény azért meglepó, mert a kutatás három éve során bármikor kérdeztünk rá a románok és a magyarok kapcsolataira (akár a kérdóívben, akár interjúkban) a viszonyt mindkét oldalról nagyon jónak minósítették.

A „telep” kifejezést a gencsiek többsége minden „hídon túl” lakóra érti, és a telepiek egyforma megítélés alá esnek. Az ott élók azonban három alteret különböztetnek meg a hídon túli részen. A faluhoz legközelebb esók szerint ók még nem is tartoznak a telephez, és nem is a híd az igazi határ, hanem a fürdó, mert „az már a magyar világban is ott állt” (tehát nem lehet román, sem pedig új, ami az erre a részre vonatkozó sztereotípia fontos eleme). Szerintük ók és a fürdó utca lakói magyarok: óket jelöltem 6.a-val.

A telepi fóutca lakosai (6.b) szerint ók sem igazi telepiek, az csak lejjebb van, a mellékutcákban (6.c), ahol szabályosan egyenesek az utcák. (A hagyományos sztereotípiában ez az elem nem is szerepel, bár logikus, hogy egy telepen egyenes utcák legyenek.) A lakosok, bár gyakran románnak vallják magukat, különbséget tesznek maguk és a telepiek között; ez utóbbiak - a helyi megítélés szerint - románul beszélnek, Avasból költöztek ide, és csobánok, azaz juhászok.

A három altér közti kapcsolatok mindenesetre jóval rétegezettebbek, mint a falu más részeihez kötódó kapcsolatok.

Az egyes, magyarok által lakott terek (2., 3., 4., 8.) mind kapcsolódnak a központhoz, ám kevéssé egymáshoz.

Valódi periférikus helyzetú falurész csupán egy van, a Kifli utca - Teremi út vidéke (5.). Hagyományosan szegény és elöregedett lakossága a központból csak áttételesen érhetó el.

Egyetlen szállal sem kötódik a falu társadalmához a közigazgatásilag hozzá tartozó „telepített” román aprófalu, Radulesti (7.) és a térben jól körülhatároltan élô harminc cigány család a Vadon utcában (9.). 
E sajátos szerkezetú kapcsolatháló magyarázatot ad egy történetre, amelyet Kató Csilla jegyzett fel 1993-as terepmunkánk alkalmával.

Egy idôs, egyedülálló özvegyasszony földjét, melyet a hölgy, mindenki tudtával, eladásra kínált fel, a református gazdák közül senki sem vásárolt meg. Ezzel lehetóvé tették, hogy a területet - a szokottnál alacsonyabb áron - egy telepi román farmer megvegye.

A történtek magyarázata szerintünk a gazdasági cselekvés beágyazottságában keresendô. A hölgy, egy régi, nagy presztízsú gazdacsalád leszármazottja, bár akkor már egyedül élt, tulajdonképpen nem volt egyedül. Volt egy felnótt fia, aki már akkor öt éve átszökött Magyarországra, és azóta nem is írt - azt sem tudták róla otthon, él-e, hal-e. Ó volt az idốs asszony reménysége. Amikor a hölgy eladásra kínálta a földjét, ezzel explicit módon azt fejezte ki, hogy nem bízik már abban, hogy a fia visszajön, gazdálkodni kezd. A többi helyi gazda akkor nemrégen kezdte a gazdálkodást jórészt a visszaszerzett birtokokon. Együttmúködésük íratlan alapszabálya a régi birtokstruktúrához való visszatérés volt, amelyben senki sem feni a fogát arra, ami a többieket „ósi jog” szerint is megilleti.

E struktúrában az asszony földjeinek is megvolt a maga helye, ezért akármelyik gazda tett volna ajánlatot, az megszegte volna az íratlan szabályt és a feltámasztott tradíciót. Ajánlatot tenni azért sem lett volna etikus - hallottuk egy másik magyarázatban -, mert a földeket az elveszett fiú számára mindenképpen tartalékolni kellett volna, hogy ó rendelkezhessen vele. Aki megveszi a földet, az ráadásul az idôs özvegy reménységét is elveszi. Ezt a felelôsséget a gazdák közül senki sem merte vállalni, így vásárolhatta meg a területet (ár alatt) a román mezógazdasági vállalkozó, akit nem befolyásolt a magyar társadalom kapcsolathálójából fakadó normatív kötöttség. 
14-milÆn.qxd 2006. 08. 04. 11:15 Page 624

624 TELEPÜlÉSKUTATÁS - VI. Mentális TéRKÉp SZERKESZTÉSE

\section{Letenyei László 1997: \\ Kőszeg mentális térképe és ingatlantérképe*}

A TeTT Consult Kft. 1997-ben a kószegi Általános rendezési terv elókészítéséhez gazdasági hatástanulmányt és ennek részeként ingatlanpiaci felmérést készitett. A tanulmány elkészitésében Jaksa Renáta, Rosivall Ágnes és Varga-Ötvös Béla nyújtott segitséget.

A kutatás célja az ingatlanpiaci helyzet felmérése és a várható tendenciák elórejelzése volt. A felmérés során kiderült, hogy az ingatlanok népszámlálási, városrendezési vagy választókörzzetek szerinti besorolása esetén nem mutathatók ki jelentósebb ingatlanpiaci különbségek az egyes városrészek között. Ez ellentmondott a kutatók által érzékelt ingatlanpiaci helyzetnek, mely szerint jelentós a különbség az egyes városrészek között. Ez indokolta a mentális terek feltérképezését, és annak vizsgálatát, hogy az egyes mentális terek ingatlanárai közt szignifikáns különbség mutatkozik-e.

A kutatás mentális térkép rajzoltatásra, interjúkra és reprezentatív kérdóives felmérésre épült. Az adatokat kvantitatív és kvalitatív módszerekkel is elemezték. A továbbiakban a szerzók szövege olvasható szerkesztett formában.

A megbízót az érdekelte, hogy melyik városnegyedben milyenek az ingatlanárak, és mik a várható tendenciák. Kérdés maradt viszont, hogy mi az a városnegyed. A népszámlálási, városrendezési vagy választókörzeteket is választhattuk volna, de azt tapasztaltuk, hogy a kószegiek nem nagyon tudták, hogy hol vannak ezeknek a formális körzeteknek a határai. A formális körzetek szerint az ingatlanpiaci árak nem mutattak területi különbségeket.

Az egyes városrészek megnevezésére a kószegieknek saját elnevezéseik voltak, amelyeket viszont a reprezentatív kérdóíves felmérés szerint megkérdezettek 98\%-a ismert. A városrészeket és a hozzájuk kötốdó jellemzéseket egy térképen szerepeltettük. Az elózóhöz hasonlóan itt is a helyi kategóriákat, elnevezéseket használtuk. Az egyes városrészek jellemzésekor az elhangzott kategóriák egyszerú gyakoriságát vettük alapul.

Hozzá kell tegyük, hogy a városrendezési körzetek megítélésünk szerint elég pontosan követik a mentális térképek határait, csak éppen több mentális teret sorolnak egy körzetbe. Az elemzések során ezért inkább következetesen saját felméréseink adataira támaszkodtunk.

A következó oldalon egy mentális térkép látható, amelyet az adatgyúijtés alapján magunk rajzoltunk. A különbözó városnegyedeket különbözó színnel jelöltük. A hozzájuk tartozó magyarázó szövegfülekben adtuk meg a városnegyed helyi elnevezését és az interjúk során leggyakrabban elóforduló sztereotip jellemzéseket.

${ }^{2}$ TeTT Consult Kft. Kézirat. 


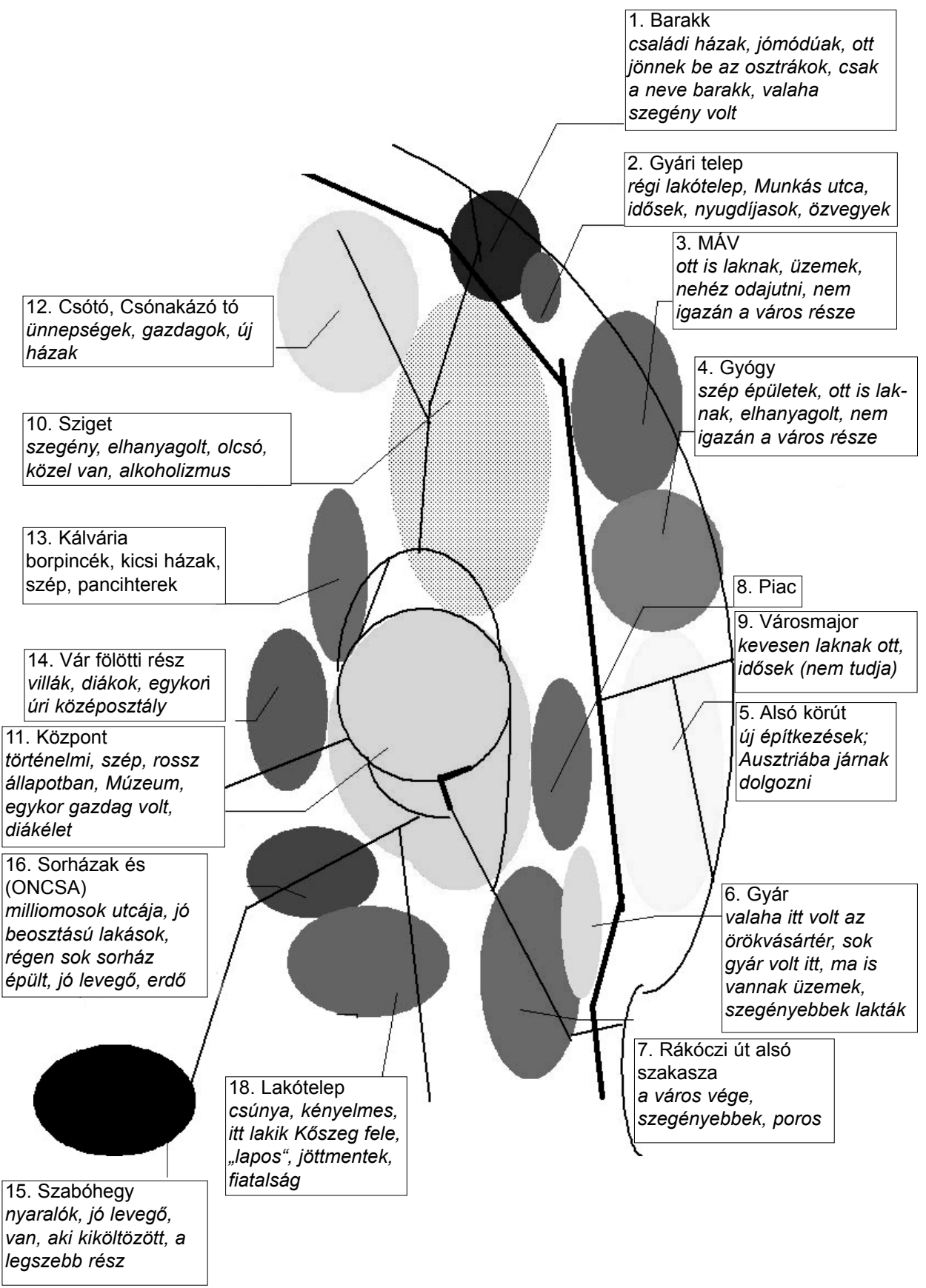

Kőszeg lakóinak mentális térképe 
A mentális térkép kategóriái alapján végre egy nyelvet beszélhettünk a kószegi lakossággal. Feladatunk az volt, hogy az így feltérképezett városnegyedek ingatlanpiaci mozgásait feltárjuk. Az alábbiakban három megközelítést mutatunk be, az elsó a tényleges adásvételekból, a második az ingatlanpiaci hirdetésekból, a harmadik pedig a piaci forgási sebességból, azaz az ingatlanok eladhatóságából indul ki. A megvalósult adásvételekre vonatkozó információkat a Megyei Illetékhivataltól kaptuk meg, ezt mutatja a következó diagram.

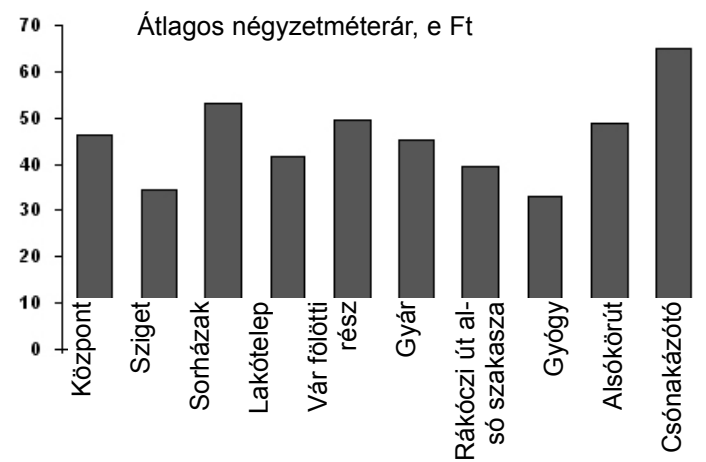

\author{
Adásvételi lakóingatlan \\ négyzetméterárak \\ városnegyedenként a \\ Megyei Illetékhivatal \\ adatai alapján
}

Egész Kószegre vonatkozóan az ingatlanok átlagára 44 ezer $\mathrm{Ft} / \mathrm{m}^{2}$ volt. A tulajdonosok azonban az ingatlanok többségét a realizálható piaci árnál 10-50 százalékkal magasabbra tartják. A következó diagramról az ingatlanok „kikiáltási ára”, azaz helyi lapokban, hirdetési újságokban megjelent kínálati ára olvasható

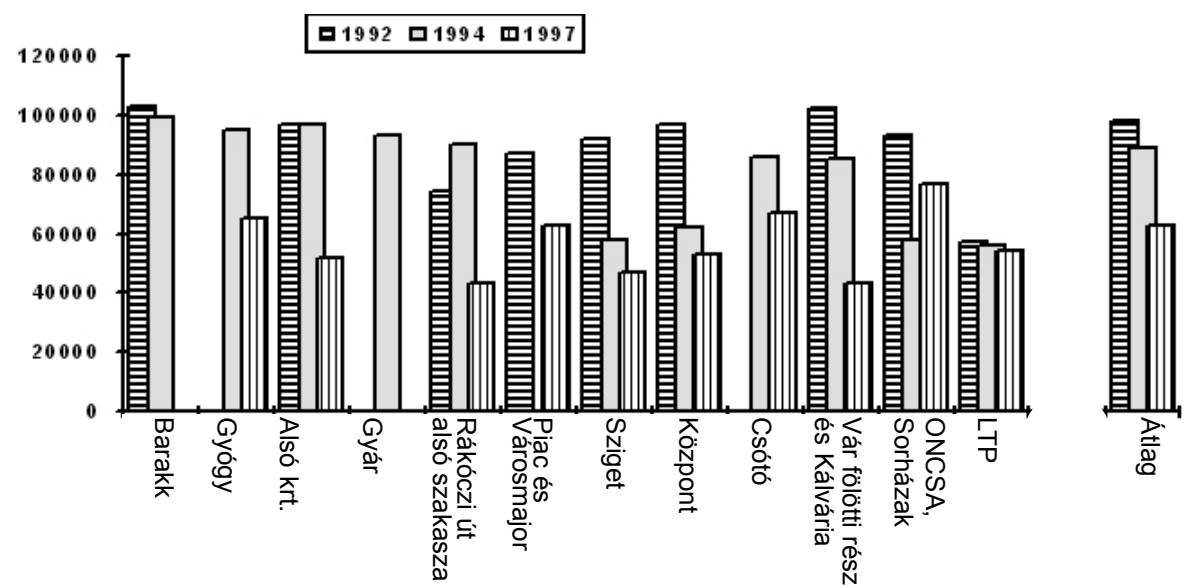

Az eladásra kínált kőszegi ingatlanok kínálati ára városnegyedenként 1992-ben, 1994-ben és 1997-ben, 1997-es árakon számolva (e Ft/m2) 
le. A diagramon az is látszik, hogy az árak 1992 óta az inflációnál lassabban növekedtek, azaz relatív áresés következett be.

1997-ben az ingatlanokat átlagosan egyharmadával magasabb áron hirdették, mint ahogy el lehetett adni. A lakótelepi és a rosszabb helyen fekvó lakások és parasztházak esetében a különbség jóval kisebb (10\% körüli) volt, mint a központi lakások és a családi házak esetében (54\%). A nagy értékú ingatlanok esetében olyan messze volt a keresleti és a kínálati ár, hogy ezek nem forogtak.

A harmadik ingatlanpiaci becsléshez az eladási árat és az eladás valószínúségét egyszerre vettük figyelembe. Az eladás valószínúségét a meghirdetett és az eladott ingatlanok hányadosa jelenti.

\begin{tabular}{|cc|}
\hline a városrész neve & $\begin{array}{c}\text { eladott ingatlanok / hirdetett } \\
\text { ingatlanok }\end{array}$ \\
\hline Barakk & 0 \\
\hline Gyári telep & 0 \\
\hline Gyógy és MÁV & 0,5 \\
\hline Alsó körút & 0,2 \\
\hline Gyár & 2,5 \\
\hline Rákóczi út alsó szakasza & 2,5 \\
\hline Sziget & 0,4 \\
\hline Piac és Városmajor & 0 \\
\hline Központ & 0,6 \\
\hline Csónakázótó környéke & 0,2 \\
\hline Vár fölötti rész & 0,7 \\
\hline Sorházak és ONCSA & 0,6 \\
\hline Lakótelep & 0,6 \\
\hline Nem ismert & 0 \\
\hline Összesen & $67 / 238=0,28$ \\
\hline
\end{tabular}

Az ingatlanok forgalmi valószínűsége |997-ben városnegyedenként

Ha a városnegyedenkénti forgalmi valószínúséget szorozzuk az átlagos eladási négyzetméterárral, olyan mutatót kapunk, amely a városnegyedek ingatlanjainak valós forgalmi értékét fejezi ki. A mutatónak elsósorban nem az abszolút értéke, hanem a többi városnegyedhez viszonyított nagysága számít. Ezt mutatja a következó oldalon látható oszlopdiagram. 


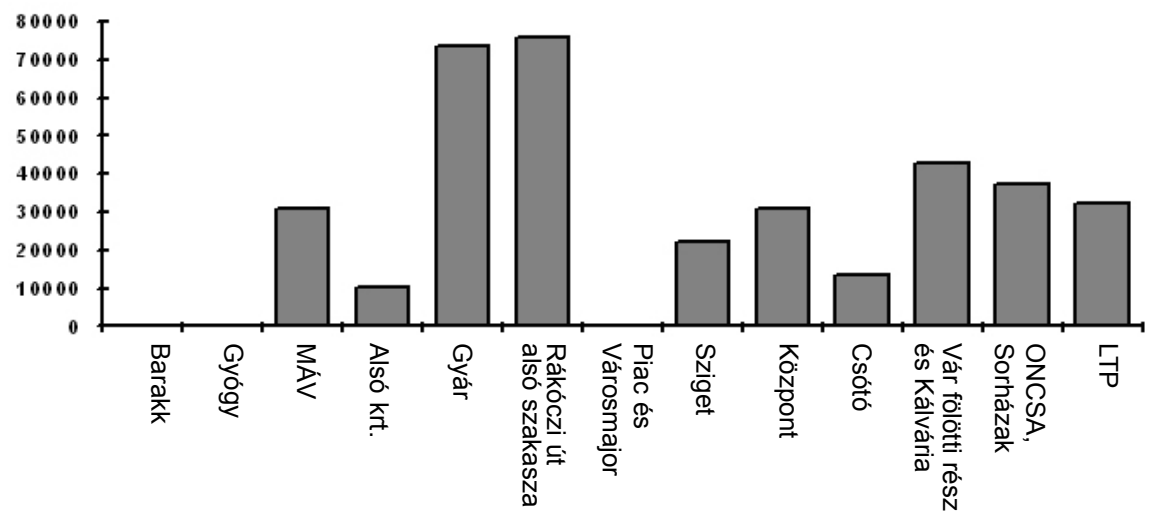

Az ingatlanok forgalmi valószínűség alapján számított piaci értéke a különböző kőszegi városnegyedekben

A diagramról leolvasható, hogy Kớszegen - a városban elhúzódó recesszió és a jövedelemkiesés miatt - éppen a kevésbé preferált ingatlanok, a lakótelepi lakások és a „külvárosi” lakások tudták megórizni az értéküket, sót, mivel ezeknek nagyobb a forgási sebességük, jobb befektetésnek számítanak, mint a jobb városnegyedekben fekvó jobb ingatlanok. Az eladási valószínúséggel szorzott ár eltér attól, amit egy értékbecsló vagy maga a tulajdonos gondolna, viszont közelebb áll a piaci realitásokhoz. Természetesen az ingatlanok nem ezen az áron kelnek el, hanem vagy magasabb áron, vagy pedig egyáltalán nem találnak vevớre.

\section{Csernák Boldizsár 2002: \\ Befogadóállomásokon élő menekültek helyismerete és térhasználati szokásai*}

Az ENSZ Menekültügyi Fóbiztosság 2002 ószén kutatást készíttetett a magyarországi befogadó állomásokon éló menekültekrót. A kutatás vezetóje Sik Endre volt. A kutatás kérdése - többek közt - az volt, hogy miként használják a menekültek a táborokat, és mennyire tudja a tábor az otthon normális körülményeit biztosítani. A kérdés megválaszolásához a kérdezóbiztos egy üres papirlapra a tábor térképét rajzoltatta interjúalanyaival. Az adatfelvételt egy kvantitatív jellegú

\footnotetext{
* Kézirat, várható megjelenés 2004 ốszén az MTA Migrációs és Menekültügyi Kutatóközpont kiadásában. A tervezett kötet szerkesztôi: Kováts András és Tóth Judit.
} 
adatfeldolgozás követte; a kutató a rajzokat elsósorban abból a szempontból értékelte, hogy különbözó tájékozódási pontok (iránypontok) hányszor fordulnak eló az egyes rajzokon. A kutatás másik itt tárgyalandó kérdése a menekültek országismeretére vonatkozott. A kérdezettek egy sematikus Magyarország-térképet kaptak, rajta 12 nagyobb település helyzetével, melyeket össze kellett kötni a mellékelt helységnevekkel. A kutatást kérdôives adatfelvétel egészitette ki, de ennek eredményei a választott szövegrészletben nem jelennek meg. A továbbiakban az eredeti szöveg egy részlete olvasható, a szerzóvel egyeztetett, rövidített és szerkesztett formában.

\section{ORSZÁGISMERET}

A válaszadók országismeretére vonatkozott - többek között - egy olyan feladat, mely során egy sematikus Magyarország-térképen kellett 12 megadott várost megnevezni.

A kérdezettek 31\%-a egyetlen magyarországi települést sem ismert fel. További $22 \%$-uk csak a fóváros és még egy város - általában saját befogadó állomásának helyzetét tudta megállapítani. A menekültek 28\%-a 3 és 5 várost tudott megnevezni. Elég nagy hányad (19\%) 6-nál több várost is helyesen be tudott jelölni.

Az országismeret szempontjából a származási hely mutatott szignifikáns különbségeket. A Kelet-közép-Európából érkezettek körében a legjobb, és a KeletÁzsia, Közép-Ázsia régióból érkezettek körében a legrosszabbak a mutatók.

A menekültek helyismeretére jellemzó, hogy harmaduk egyet sem, több mint felük legfeljebb 1-2 várost ismer az országban. Egynegyedük ezzel szemben

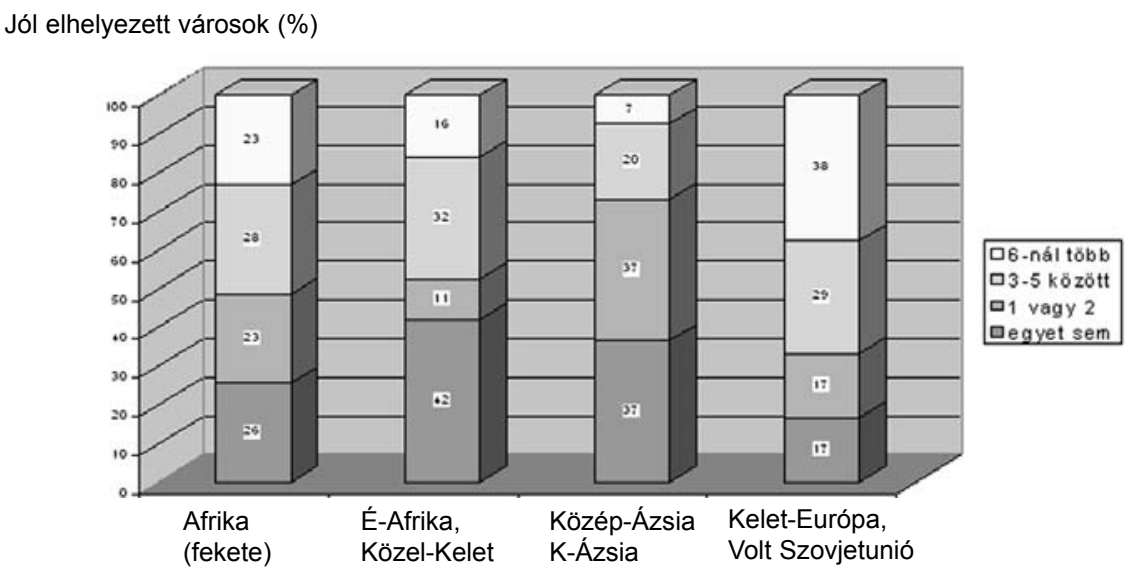


6-nál több várost tudott elhelyezni a sematikus térképen.

A menekülttáborok mentális térképére vonatkozó kutatás legfontosabb adatforrása a bicskei, a debreceni és a békéscsabai menekülttáborban a 147 kérdezett által készített 92 rajz mint saját mentális térképük. A rajzoltatás több szempontból is jó módszernek bizonyult. Egyrészt, kontrollált a táborlakók környezete és az ahhoz való viszony. Másrészt, a rajzok kevésbé szülnek ellenérzést, bizalmatlanságot a speciális helyzetben lévố válaszadók körében, mint a kérdóíves megkérdezés. Harmadrészt, a rajz segít a kulturális különbség áthidalásában viszonylag független a származástól, társadalmi helyzettól és életkortól, az eredmények könnyen összehasonlíthatók.

A térképek segítségével megismerhetjük a menekültek táborészlelését, táborhasználati szokásait és a táborok szolgáltatásainak eredményességét. A rajzok alapján kiderül, hogy a tábor helyszínei közül melyek a fontosak a lakók számára. Módszertanilag az elemzésnek ezt a szakaszát úgy oldottuk meg, hogy a rajzokon elóforduló helyszíneket számítógépes adatbázisban rögzítettük.

Az elófordulási gyakoriság mentén sorrend alakítható ki, amely aztán összevethetó az egyes táborok vagy a menekült származása mentén. Az épületek csoportosíthatóak funkcióik szerint: típusokat alkotnak a hivatalos épületek, az alapvetó szükségleteket kielégító épületek, vagy a szórakozással kapcsolatos épületek csoportjai. A berajzolt útvonalak alapján képet kaphatunk a táborlakók életformájáról, aktivitásáról, és ezek alapján lelki állapotáról. A táborok felól közelítve megismerhetjük az egyes táborok kihasználtságát, ha összehasonlítjuk a használt épületeket az összes épülettel.

A táborok eltéró alaprajzstruktúrája és építészeti megoldása torzítást okoz, amit sajnos nem lehet kiküszöbölni. A többfunkciós épületek általában csak az egyik szolgáltatás alapján vannak elnevezve a rajzokon, holott elófordulhat, hogy a rajzoló nemcsak azt használja. A debreceni menekülttáborban például az internetszoba az egyik lakóépületben van, a szociális munkások irodái pedig az információs ház nevú épületben találhatók.

A következó diagram azokat a szolgáltatásokat összegzi, amelyek mindhárom táborban fellelhetóek. Az adatokat súlyoztuk, a súlyozás eredményeként az egyes táborok ugyanakkora szerepet kapnak. Az ábrán található százalék azt jelenti, hogy adott épület/szolgáltatás az összes rajz hány százalékán volt fellelhetó. 


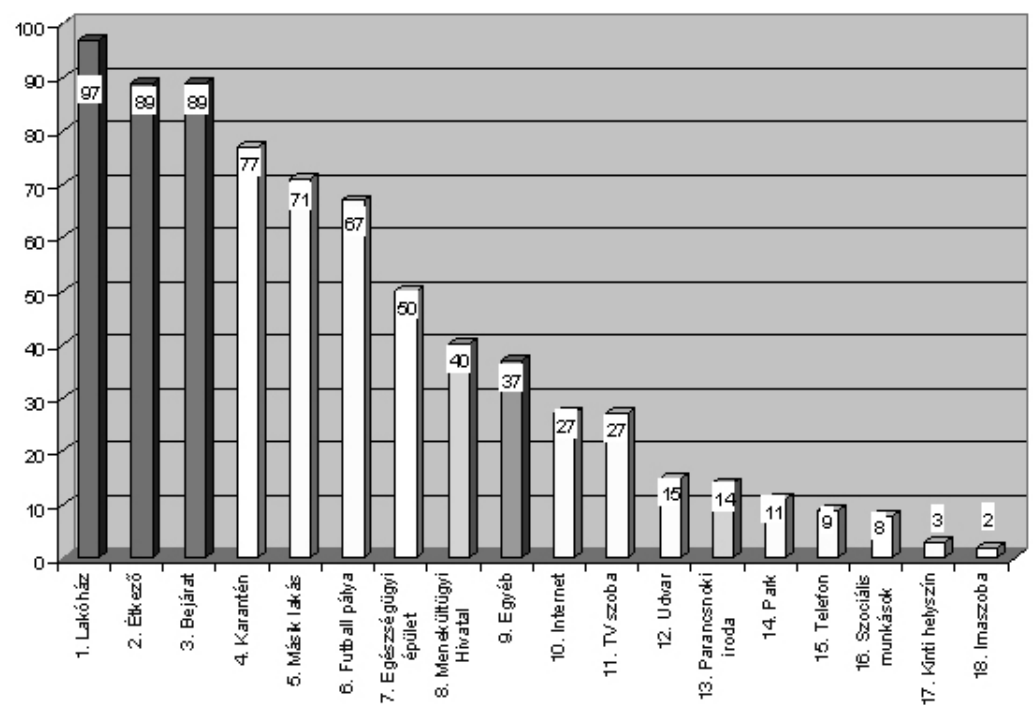

Az adott épület vagy szolgáltatás előfordulási gyakorisága a rajzokon, a három táborban összesen

A kutatás alapján megállapitható volt, hogy a tábori körülmények korlátozottan basonlítanak az otthoni, megszokott körülményekre, a tábor inkább az alapvetó szükségletek ellátását, a menekült „túlélését” biztosítja. Erre utal, bogy a rajzokon leggyakrabban az alapvetô szükségleteket, az alvást és a táplálkozást szolgáló épületek, a Lakóbáz és az Étkezó fordulnak eló. A gyakorisági sorban ezután a menekültek közösségi tevékenységét kielégitó létesitmények következnek, mint a Focipálya vagy a Másik lakás, azaz egy másik menekült meglátogatása. Ezután következik a Menekültügyi Hivatal, melynek gyakorlati szerepe mellett szimbolikus jelentósége is nagy, biszen kapcsolódási pont a külvilággal, a belyi batóságokkal. Csernák. Boldizsár megjegyzi, bogy „sokat elárul a Hivatallal kapcsolatos érzelmekról, hogy sok rajzon "police"felirattal illetik". 


\section{Letenyei László 2002: Eger mentális térképe*}

Eger rendezési tervét a Rosivall Kft. készítette. A tervezói munka során a megbizó egri önkormányzat munkatársai felhîvták a tervezófigyelmét a történelmi városrészek kiemelt szerepére a város életében. Elvárásként fogalmazták meg, hogy az egyes városrészek karakterére legyenek tekintettel a tervezói munka során. A Rosivall Kft. ezért kérte fel a TeTT Consult Kft.-t. A kutatáshoz elózetes információként két dokumentumot kaptunk: az egri várostérképet, mely feltünteti a történelmi városrész-kategóriákat, illetve Eger Város Történelmi Városrészeinek térképét, melyet 1992-ben a Váti Kht. részére az egyik önkormányzati dolgozó állított össze.

A kutatási kérdés az volt, hogy a történelmi városrészek napjainkban is megórizték-e sajátos karakterüket. Ha igen, akkor hol hüzódnak a határaik, és miként jellemezhetók ezek a karakterek? Miként jelenjen meg mindez a készüló rendezési tervben?

A kutatók abból indultak ki, hogy ezúttal nem Eger történelmi városrész térképét, hanem kortárs mentális térképét akarjāk elkészíteni. A történelmi városrészek egy adott városban a történelmi korok mentális térképét tükrözik, azaz évszázadokon át rögzült egykori közigazgatási határokat és a „helyek szellemét”. A (kortárs) mentális térkép a ma érvényesnek tekintett városrészeket és azok karaktereit tükrözi, amelyek részben a tradición (történelmi városrészeken), részben pedig a mai hétköznapi élet tapasztalatain alapulnak.

A kutatók az adatgyújtést interjúsorozattal és telefonos közvélemény-kutatással végezték. A továbbiakban a szerzó szövege olvasható szerkesztett formában.

Eger város mentális térképének elkészítéséhez a következó elớzetes dokumentumokat kaptuk:

- Eger Város Történelmi Városrészeinek térképe. Eger Önkormányzata 1992;

- Heves Megyei Illetékhivatal, városrészenkénti csoportosítás, 2001;

- Eger várostérkép városrész-elnevezései, Nyír-Karta, Topográf, 2002.

A három forrás különbözött egymástól. Az eltéréseket, illetve a saját adatgyúijtésból származó városrész-elnevezéseket mutatja a következó táblázat.

\footnotetext{
* TeTT Consult Kft. Kézirat.
} 


\begin{tabular}{|c|c|}
\hline 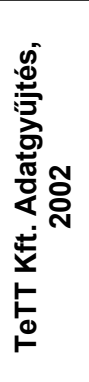 & 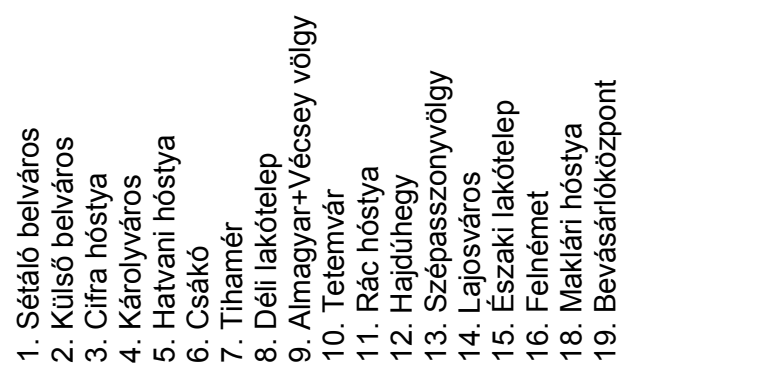 \\
\hline 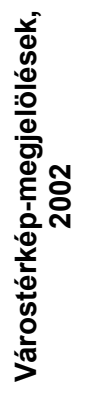 & 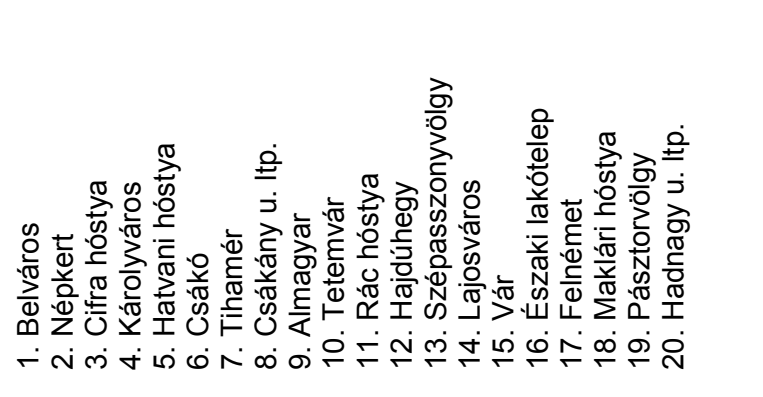 \\
\hline 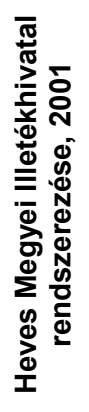 & 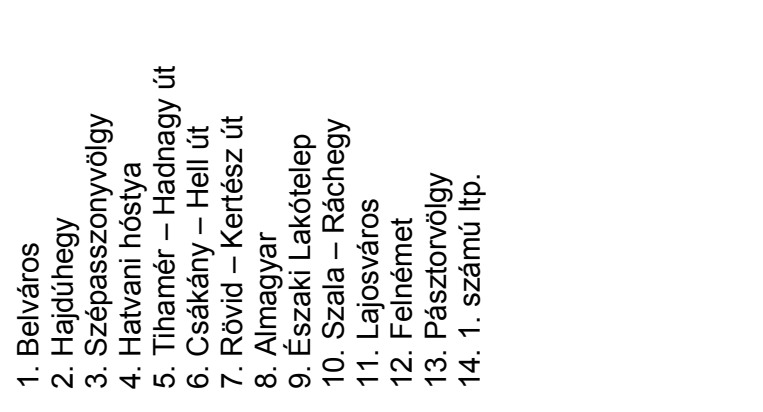 \\
\hline 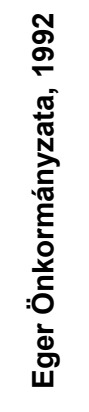 & 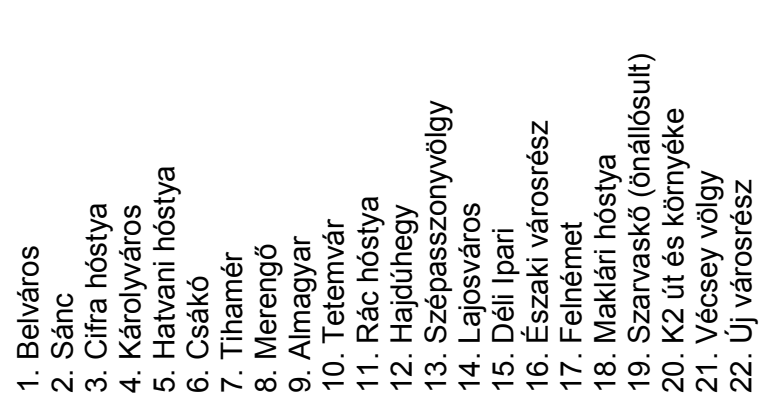 \\
\hline
\end{tabular}


Eger városrészei,

Eger város önkormányzata (1992) nyomán

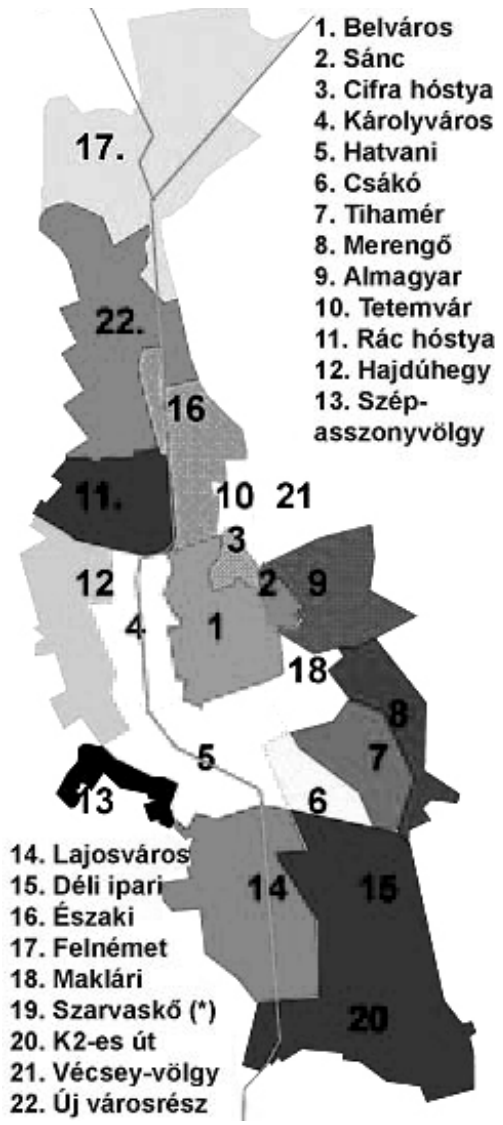

Eger mentális térképe, 2002

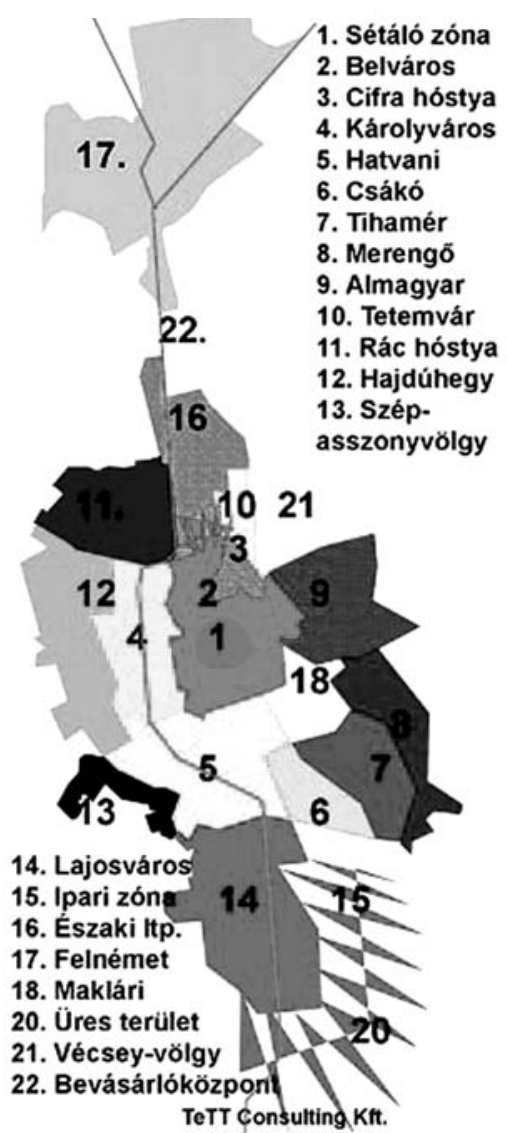

Eger városrészei. Eger Önkormányzata (1992) illetve a TeTT Consulting lakossági interjúi és kérdőíves felmérése (2002) adatai alapján

Megállapítható volt, hogy Egerben a hagyományos (történelmi) városrészeknek és elnevezéseiknek a hétköznapi tájékozódásban és tudásban nagy jelentósége van, de az erre vonatkozó tudás nem egységes. A város szerves fejlódése során egyes városrészek funkciói, illetve határai átalakultak, ezért ezek újbóli megállapítására feltétlenül szükség van. Evégból elôször interjúsorozatot készítettünk a település néhány ingatlanközvetító cégével. Az interjúk alapján a legtöbb városrész kognitív érvényességét (azaz, hogy a város mai lakosai szerint egy létezó vagy egy nem létezó városrészról van szó) sikerült megállapítani. A kérdéses helyekre személyesen is elmentünk, és abban a negyedben éló, azt jól ismeró emberekkel készítettünk interjúkat. Ezek alapján körvonalazódott a mi képünk Egerról. 
SZATHMÁRI MILÁN (SZERK.): HAZAI PÉLDÁK...

\begin{tabular}{|c|c|c|c|c|c|}
\hline $\begin{array}{c}\text { Városrész } \\
\text { Eger } \\
\text { önkormányzata } \\
\text { szerint (1992) }\end{array}$ & $\begin{array}{c}\text { Határ } \\
\text { törésvonal }\end{array}$ & Iránypontok & $\begin{array}{c}\text { Fö } \\
\text { útvonalak }\end{array}$ & $\begin{array}{l}\text { Csomó- } \\
\text { pontok }\end{array}$ & $\begin{array}{l}\text { Sztereo- } \\
\text { típiák }\end{array}$ \\
\hline 1. Belváros & $\begin{array}{l}\text { Vár, Népkért, } \\
\text { vasút, } \\
\text { Tü zoltó tér }\end{array}$ & $\begin{array}{l}\text { TESCO, } \\
\text { Kultúrház, } \\
\text { Minaret stb. }\end{array}$ & $\begin{array}{l}\text { Belvároson } \\
\text { belül. Átjárók. } \\
\text { Észak-Dél } \\
\text { útvonal }\end{array}$ & $\begin{array}{l}\text { Dobó tér, } \\
\text { Minaret, } \\
\text { Főiskola }\end{array}$ & $\begin{array}{l}\text { Vendégsze- } \\
\text { retet, régi } \\
\text { egriek }\end{array}$ \\
\hline 2. Sánc & Szarvas tér & Iskola & Nincs adat & $\mathrm{NA}^{*}$ & Jók \\
\hline 3. Cifra hóstya & $\begin{array}{l}\text { Vár, } \\
\text { domboldal }\end{array}$ & $\begin{array}{l}\text { Vasút- } \\
\text { állomás, Vár }\end{array}$ & $\begin{array}{l}\text { Belváros felé, } \\
\text { észak felé }\end{array}$ & $\begin{array}{l}\text { Vasúti átkelő, } \\
\text { Cifrakapu tér }\end{array}$ & $\begin{array}{l}\text { Kedves } \\
\text { emberek }\end{array}$ \\
\hline 4. Károlyváros & Táblák & $\begin{array}{l}\text { Busz- } \\
\text { megállók }\end{array}$ & $\begin{array}{l}\text { Lajostér, } \\
\text { Belváros }\end{array}$ & $\begin{array}{l}\text { Kisasszony } \\
\text { út }\end{array}$ & $\begin{array}{l}\text { Rendesek, } \\
\text { igyekvők }\end{array}$ \\
\hline 5. Hatvani hóstya & $\begin{array}{l}\text { Laktanyaút, } \\
\text { fő útvonal }\end{array}$ & $\begin{array}{l}\text { Állomás, } \\
\text { templom }\end{array}$ & $\begin{array}{l}\text { Belváros felé, } \\
\text { vasút felé }\end{array}$ & $\begin{array}{l}\text { APEH, } \\
\text { vasút- } \\
\text { állomás }\end{array}$ & $\begin{array}{l}\text { Elmaradott } \\
\text { környék }\end{array}$ \\
\hline 6. Csákó & Népkert & Iskola, mozi & Fő útvonal & $\begin{array}{l}\text { Vasút- } \\
\text { állomás }\end{array}$ & Kedvesek \\
\hline 7. Tihamér & Deák F. út & Strand, vár & $\begin{array}{l}\text { Kertész, } \\
\text { hadnagy }\end{array}$ & központ & Vegyesek \\
\hline 8. Merengő & NA & & & & \\
\hline 9. Almagyar & Sánc & Iskola & $\begin{array}{l}\text { Dobó tér, } \\
\text { Vörös M. }\end{array}$ & $\begin{array}{l}\text { Szarvas tér, } \\
\text { posták }\end{array}$ & Kedvesek \\
\hline 10. Tetemvár & $\begin{array}{l}\text { Cira kapu út, } \\
\text { török frigyes }\end{array}$ & Üzletek & Fő útvonal & $\begin{array}{l}\text { Tesco busz- } \\
\text { megállok }\end{array}$ & Egyszerü ek \\
\hline 11. Rác hóstya & $\begin{array}{l}\text { Kerecsény, } \\
\text { Ostoros }\end{array}$ & Templom & központ & Üzleteknél & Vegyesek \\
\hline 12. Hajdúhegy & $\begin{array}{l}\text { Busz- } \\
\text { forgalom }\end{array}$ & $\begin{array}{l}\text { Iskolák, } \\
\text { üzletek }\end{array}$ & centrum & 4 sávos & Normálisak \\
\hline \multicolumn{6}{|l|}{$\begin{array}{l}\text { 13. Szépasszony- } \\
\text { völgy }\end{array}$} \\
\hline 14. Lajosváros & $\begin{array}{l}\text { Vasút- } \\
\text { állomás }\end{array}$ & Üzletek stb. & Mátyás út & postánál & Vegyesek \\
\hline 15. Déli Ipari & NA & NA & NA & NA & NA \\
\hline $\begin{array}{l}\text { 16. Északi } \\
\text { városrész (északi } \\
\text { lakótelep) }\end{array}$ & $\begin{array}{l}\text { Olasz út, } \\
\text { Háztípus }\end{array}$ & $\begin{array}{l}\text { Templom, } \\
\text { polgárm. } \\
\text { hivatal }\end{array}$ & $\begin{array}{l}\text { Rákóczi, } \\
\text { Cifrakapu }\end{array}$ & $\begin{array}{l}\text { Tesco, } \\
\text { centrum }\end{array}$ & $\begin{array}{l}\text { Szegényeb- } \\
\text { bek. Ma már } \\
\text { nincs } \\
\text { különbség }\end{array}$ \\
\hline \multicolumn{6}{|l|}{ 17. Felnémet } \\
\hline 18. Maklári hóstya & Szarvas tér & Iskolák & Kertész utca & $\begin{array}{l}\text { Posta, } \\
\text { templom }\end{array}$ & Türelmesek \\
\hline $\begin{array}{l}\text { 19. Szarvaskő } \\
\text { (önállósult) }\end{array}$ & NA & NA & NA & NA & NA \\
\hline $\begin{array}{l}\text { 20. K2 út és } \\
\text { környéke }\end{array}$ & NA & NA & NA & NA & NA \\
\hline 21. Vécsey völgy & $\begin{array}{l}\text { Kerületek, } \\
\text { almagyar }\end{array}$ & $\begin{array}{l}\text { Templom } \\
\text { iskola, óvoda }\end{array}$ & $\begin{array}{l}\text { Tetemvárút, } \\
\text { várállomás }\end{array}$ & $\begin{array}{l}\text { Szarvas tér, } \\
\text { Maklári, } \\
\text { andornai }\end{array}$ & $\begin{array}{l}\text { Ember- } \\
\text { ségesek }\end{array}$ \\
\hline \multicolumn{6}{|l|}{ 22. Új városrész } \\
\hline 30. Ostoros & Eger tavai & $\begin{array}{l}\text { Üzletek, } \\
\text { iskola }\end{array}$ & Petőfi & $\begin{array}{l}\text { Központ } \\
\text { Bér utca }\end{array}$ & Rendesek \\
\hline 31. Egerszalók & Határút & Templom stb. & Egri utca & Centrum & Öszinték \\
\hline 32. Andornaktálya & Tábla & $\begin{array}{l}\text { Áruházak, } \\
\text { posta }\end{array}$ & Széchényi & $\begin{array}{l}\text { Busz- } \\
\text { megállók }\end{array}$ & Vegyesek \\
\hline 33. Felsőtárkány & Andor, Eger & $\begin{array}{l}\text { Polgármes- } \\
\text { teri hivatal }\end{array}$ & Fő útvonal & $\begin{array}{l}\text { Óvodáknál, } \\
\text { buszoknál }\end{array}$ & Kedvesek \\
\hline
\end{tabular}

* NA - Nincs adat

Eger város mentális térképeinek elemei 
636 TelepülésKuTATÁs - VI. Mentális térkÉp sZerkesztése

A mentális térkép megrajzolása után az volt a kérdés, hogy az egriek többsége szerint is úgy néz-e ki Eger, mint ahogy mi látni véltük néhány napos interjúsorozatunk végére. Ennek megállapítására telefonos közvélemény-kutatást végeztünk, egy 500 fós, városrészenként rétegezett véletlen minta alapján. Az eredményeket táblázatban foglaltuk össze. A következó táblázat az egriek mentális térképének legfontosabb elemeit tartalmazza: az egyes mentális terek megnevezését, határait, tájékozódási pontjait, útvonalait, csomópontjait és a városrészhez kötódó leggyakrabban elhangzó asszociációkat.

A „lokálpatrióta index” azt mutatja, hogy a városnegyedbeli válaszadók - a más városnegyedbeliekhez képest - milyen régóta élnek az adott városnegyedben. Minél magasabb ez a szám, feltehetóen annál inkább kötódnek a városnegyedhez a válaszadók. Kiszámítását az indokolta, hogy bizonyos városrészek lakosai - noha tréfásan - megemlítették, hogy más városrészek lakói csak „gyüttmentek" hozzájuk képest. Az index segíthet tisztább képet kapni e kérdésben.

A történelmi városrészek és a mai városrészek nagymértékben fedik egymást, ami Magyarországon ritka. Ennek ellenére a város szívében jelentós változások történtek: a mentális térképról eltúnt a Sánc, legfeljebb az ott lakók használják ezt a kategóriát, az ingatlanpiac és a kívülállók nem. A belváros egy részét sétálóutcákká alakították. A mentális térképen a belvárosnak ez a része Sétálózónaként önállóvá alakult. Ezt a változást az ingatlanpiac is tükrözi: az árak szignifikánsan magasabbak, mint belváros többi részén. 
SZATHMÁRI MILÁN (SZERK.): HAZAI PÉLDÁK.

\begin{tabular}{|c|c|c|c|c|}
\hline $\begin{array}{c}\text { Városrész, Váti } \\
\text { (1992) besorolás } \\
\text { szerint }\end{array}$ & $\begin{array}{l}\text { Lokál- } \\
\text { patrióta } \\
\text { index }\end{array}$ & $\begin{array}{l}\text { A városrész } \\
\text { viszonya Eger } \\
\text { várossal }\end{array}$ & Hiányolt szolgáltatás & $\begin{array}{c}\text { A városrész javasolt } \\
\text { funkciója } \\
\text { (leggyakrabban első } \\
\text { helyen említett) }\end{array}$ \\
\hline 1. Belváros & 100 & Harmonikus & $\begin{array}{l}\text { Semmi, utak, } \\
\text { gyógyszertár }\end{array}$ & $\begin{array}{l}\text { Lakóövezet, } \\
\text { idegenforgalom, } \\
\text { kisvállalkozás }\end{array}$ \\
\hline 2. Sánc & 65 & Háttérbe szorított & Utak & Egyéb \\
\hline 3. Cifra hóstya & 93 & $\begin{array}{l}\text { Harmonikus, kissé } \\
\text { elönyös }\end{array}$ & Semmi, mozi & $\begin{array}{l}\text { Lakóövezet, } \\
\text { kisvállalkozás }\end{array}$ \\
\hline 4. Károlyváros & 82 & $\begin{array}{l}\text { Harmonikus, kissé } \\
\text { hátrányos }\end{array}$ & $\begin{array}{l}\text { Utak, gyógyszertár, } \\
\text { szórakozóhely }\end{array}$ & $\begin{array}{l}\text { Lakóövezet, } \\
\text { idegenforgalom }\end{array}$ \\
\hline 5. Hatvani hóstya & 100 & $\begin{array}{l}\text { Harmonikus, kissé } \\
\text { hátrányos }\end{array}$ & $\begin{array}{l}\text { Fodrász-kozmetika, } \\
\text { szórakozóhely, mozi, } \\
\text { hentes, posta, } \\
\text { gyógyszertár }\end{array}$ & $\begin{array}{l}\text { Lakóövezet, } \\
\text { kisvállalkozás }\end{array}$ \\
\hline 6. Csákó & 59 & Harmonikus & Utak, szórakozóhely & Lakóövezet \\
\hline 7. Tihamér & 52 & $\begin{array}{l}\text { Harmonikus, kissé } \\
\text { elönyös }\end{array}$ & $\begin{array}{l}\text { Utak, sok minden, } \\
\text { hentes, gyógyszertár }\end{array}$ & $\begin{array}{l}\text { Lakóövezet, } \\
\text { idegenforgalom }\end{array}$ \\
\hline 8. Merengő & $\mathrm{NA}$ & $\mathrm{NA}^{*}$ & NA & NA \\
\hline 9. Almagyar & 73 & Előnyös helyzetü & Semmi, sok minden & $\begin{array}{l}\text { Lakóövezet, } \\
\text { idegenforgalom, } \\
\text { kisvállalkozás }\end{array}$ \\
\hline 10. Tetemvár & NA & & & \\
\hline 11. Rác hóstya & NA & & & \\
\hline 12. Hajdúhegy & 76 & $\begin{array}{l}\text { Inkább hátrányos } \\
\text { helyzetű }\end{array}$ & $\begin{array}{l}\text { Gyógyszertár, } \\
\text { szórakozóhely, sok } \\
\text { minden }\end{array}$ & $\begin{array}{l}\text { Lakóövezet, } \\
\text { kisvállalkozás }\end{array}$ \\
\hline $\begin{array}{l}\text { 13. Szépasz- } \\
\text { szonyvölgy }\end{array}$ & NA & & & \\
\hline 14. Lajosváros & 65 & $\begin{array}{l}\text { Harmonikus, kissé } \\
\text { előnyös helyzetű }\end{array}$ & $\begin{array}{l}\text { Utak, hentes, semmi, } \\
\text { szórakozóhely }\end{array}$ & $\begin{array}{l}\text { Lakóövezet, } \\
\text { idegenforgalom, } \\
\text { kisvállalkozás }\end{array}$ \\
\hline 15. Déli Ipari & $\mathrm{NA}$ & & & \\
\hline $\begin{array}{l}\text { 16. Északi } \\
\text { városrész (északi } \\
\text { lakótelep) }\end{array}$ & 65 & Harmonikus & $\begin{array}{l}\text { Utak, szórakozóhely, } \\
\text { fodrász-kozmetika, } \\
\text { hentes, mozi }\end{array}$ & Lakóövezet \\
\hline 17. Felnémet & 86 & $\begin{array}{l}\text { Inkább hátrányos } \\
\text { helyzetű }\end{array}$ & $\begin{array}{l}\text { Utak, távol van Egertöl, } \\
\text { sok minden }\end{array}$ & $\begin{array}{l}\text { Lakóövezet, } \\
\text { kisvállalkozás }\end{array}$ \\
\hline 18. Maklári hóstya & 91 & Harmonikus & $\begin{array}{l}\text { Sok minden, } \\
\text { gyógyszertár, posta }\end{array}$ & Lakóövezet \\
\hline $\begin{array}{l}\text { 19. Szarvaskő } \\
\text { (önállósult) }\end{array}$ & NA & & & \\
\hline $\begin{array}{l}\text { 20. K2 út és } \\
\text { környéke }\end{array}$ & NA & & & \\
\hline 21. Vécsey völgy & NA & & & \\
\hline 22. Új városrész & NA & & & \\
\hline 30. Ostoros & 45 & Előnyös helyzet & $\begin{array}{l}\text { Szórakozóhely, semmi, } \\
\text { posta }\end{array}$ & $\begin{array}{l}\text { Kisvállalkozás, } \\
\text { idegenforgalom, } \\
\text { lakóövezet }\end{array}$ \\
\hline 31. Egerszalók & 41 & Elönyös helyzet & $\begin{array}{l}\text { Szórakozóhely, } \\
\text { gyógyszertár, sok } \\
\text { minden, utak, posta }\end{array}$ & $\begin{array}{l}\text { Kisvállalkozás, } \\
\text { lakóövezet, } \\
\text { idegenforgalom }\end{array}$ \\
\hline 32. Andornak-tálya & 23 & Harmonikus viszony & $\begin{array}{l}\text { Szórakozóhely, fodrász, } \\
\text { gyógyszertár, posta }\end{array}$ & $\begin{array}{l}\text { Kisvállalkozás, } \\
\text { lakóövezet }\end{array}$ \\
\hline 33. Felsőtárkány & 96 & Előnyös helyzet & Mozi, fodrász-kozmetika & $\begin{array}{l}\text { Kisvállalkozás, } \\
\text { lakóövezet }\end{array}$ \\
\hline
\end{tabular}

*NA - Nincs adat

Eger városrészeinek néhány sajátsága 
638 TELEPÜlÉSKUTATÁS - VI. MENTÁlIs TÉRKÉP SZERKESZTÉSE

\section{Garamhegyi Ábel: Mentális térképek: egy holland példa*}

A városmarketing számára fontos például, hogy lakosaink hogyan ítélik meg a közbiztonságot vagy a befektetók mennyire ítélnek „isten háta mögöttinek” egy területet (Solomon, 1978). Ezek a módszerek általában valamely térképi ábrázolásra történó jelölésen alapultak. A következó két hollandiai példa ezt mutatja be. Az elsó esetben a Groningen város lakosaiból képzett mintának kellett bejelölni az általuk legkevésbé biztonságosnak tartott utcákat. Ezáltal alakult ki mindkét bemutatott térkép, részint a „legfélelmetesebb” utcákról, közterületekról, részint pedig a közbiztonság térbeli eloszlásáról (Ashworth, 1997). Felesleges hangsúlyozni, hogy ezen térképek ismeretében a város vezetói könnyen elhelyezhetik rendóreik állandó helyét, és tervezhetik ellenórzó körútjaikat, leghatékonyabban fokozva a lakosok biztonságérzetét, tetemesen „feljavítva” ezáltal a helyterméket (lásd a következó két ábrát). A második térképen Hollandia vállalkozóinak telephelyválasztási szokásait kísérelték meg felderíteni. A befektetókból képzett minta tagjainak a térképen elóre bejelölt pontokat kellett megjelölniük aszerint, hogy telepítenék-e következó üzemüket a településre. A pontok egy része valós várost, más része azonban nem létezó települést takart. Az eloszlásuk így többé-kevésbé hálószerú volt. (Ebben a térbeli dimenzióban különbözött a módszer egy egyszerú lekérdezéses technikától!) A kapott válaszok - és azok célcsoportok szerinti leválogatása - izovonalak (az azonos számú kiválasztást elért pontokat összekötó görbék) segítségével ábrázolták a telephelyre vonatkozó preferenciákat (Pellenbarg, 1996).

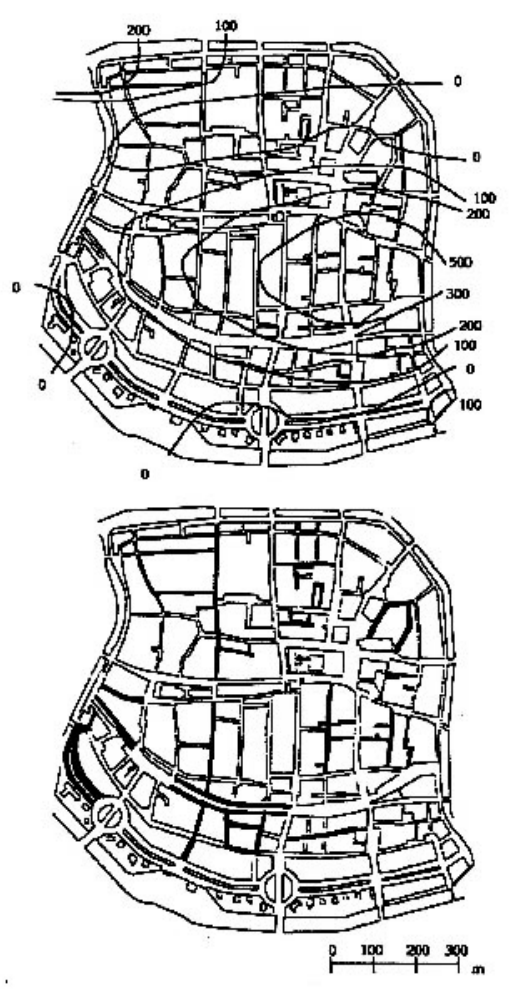

A félelem földrajza Groningenben I. (Forrás: Ashworth [1997] 7. ábra)

\footnotetext{
${ }^{5}$ Doktori értekezés. 2001. (Részlet)
} 
a) átlag

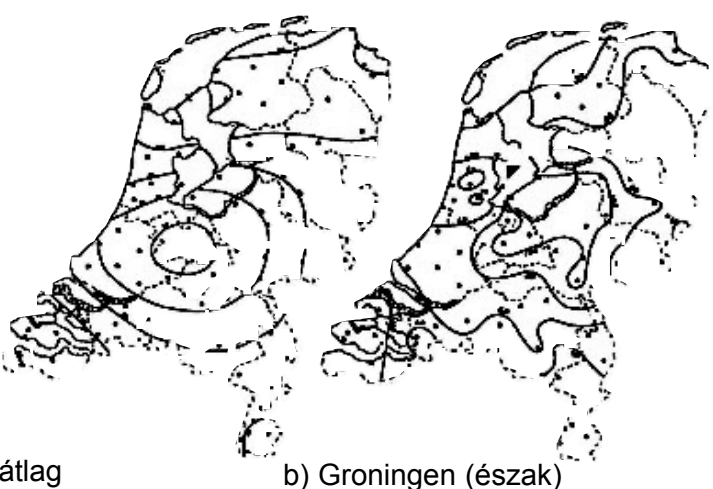

b) Groningen (észak)

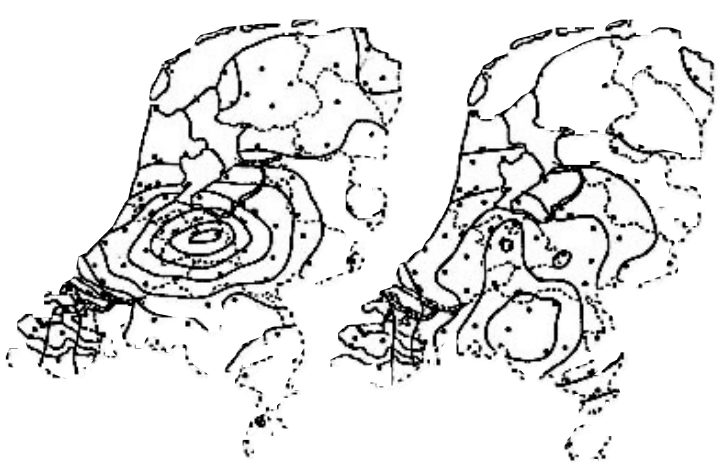

c) Utrecht (centrum) d) N. Brabant

(dél)
A félelem földrajza Groningenben II. (Forrás: Ashworth [1997] 7. ábra)

\section{Letenyei László, Babarczi Annamária Marica és Lengyel Linda Márta 2003: Cece község mentális térképe*}

Cece mentális térképe a települési önkormányzat megbízásából készült 2003ban. A tanulmány a településfejlesztési koncepció alapját képezte. A kutatás kérdése - egyebek közt - az volt, hogy miként lebetne a falu központjának úgy egy sajátos karakter adni, bogy közben a település többi része is egyenletesen fejlódbessen. A kutatás során a résztvevó megfigyelést, fénymásolt térkép alapon végzett mentális térkép rajzoltatást és interjúsorozatot végeztek a kutatók. A továbbiakban a tanulmány részlete olvasható.

\footnotetext{
* TeTT Consult Kft. Kézirat.
} 


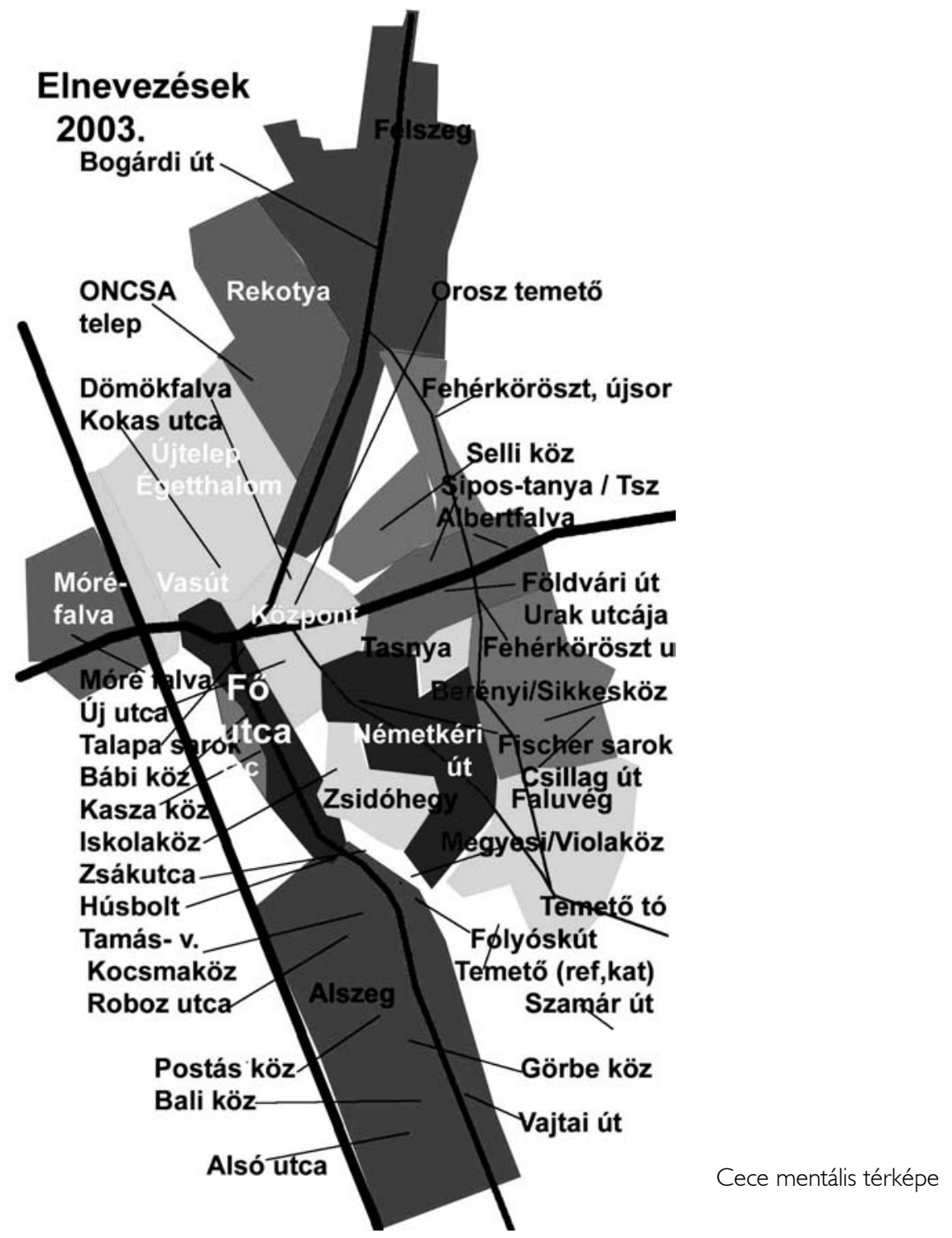

Az önkormányzattól kaptunk Cece-térképet, és megkértük a lakosokat, hogy jelöljék be az általuk ismert falurészeket és azok legfontosabbnak tartott helyeit, csomópontjait. A következókben Cece mentális térképét, helyi elnevezések utcajegyzékét, majd a levonható következtetéseket és javaslatokat mutatjuk be. 
A következó kifejezésekkel találkoztunk:

\begin{tabular}{|c|c|}
\hline Helyi elnevezés & Hivatalos elnevezés \\
\hline \multicolumn{2}{|c|}{ FALURÉSZEK } \\
\hline Rekotya & \\
\hline Tasnya & $\begin{array}{l}\text { Gyóni Géza /József } \\
\text { Attila utca }\end{array}$ \\
\hline Alszeg & - \\
\hline Égetthalom & Táncsics Mihály utca \\
\hline ONCSA / Újtelep & $\begin{array}{l}\text { Dózsa György / Ady } \\
\text { Endre utca }\end{array}$ \\
\hline Központ & - \\
\hline Felszeg & Köztársaság útja \\
\hline Zsidóhegy & - \\
\hline Piac/Bábikör & - \\
\hline Móréfalva & Arany János utca \\
\hline Albertfalva & - \\
\hline Dömökfalva & - \\
\hline Faluvég & - \\
\hline Sárréte & Sárrét \\
\hline \multicolumn{2}{|c|}{ TÁJÉKOZÓDÁSI PONTOK } \\
\hline $\begin{array}{l}\text { Temető tó } \\
\text { Orosz temető }\end{array}$ & \\
\hline Folyóskút & Artézi kút \\
\hline
\end{tabular}

\begin{tabular}{|c|c|}
\hline Helyi elnevezés & Hivatalos elnevezés \\
\hline \multicolumn{2}{|c|}{ UTCANEVEK } \\
\hline Fő utca & Deák Ferenc utca \\
\hline $\begin{array}{l}\text { Urak utcája / } \\
\text { Földvári út }\end{array}$ & Árpád utca \\
\hline Bogárdi út & Köztársaság útja \\
\hline Vajtai út & Deák Ferenc utca \\
\hline $\begin{array}{l}\text { Németkéri út / } \\
\text { Botka uca }\end{array}$ & Kossuth Lajos utca \\
\hline Fehérköröszt / Újsor & Bethlen Gábor utca \\
\hline Talapa sarok & Szabadság tér \\
\hline Fischer sarok & - \\
\hline Új utca & Jókai Mór utca \\
\hline Iskolaköz & Petőfi Sándor utca \\
\hline Kokas utca & Bartók Béla utca \\
\hline Szamár út & Fecske utca \\
\hline Görbeköz & Akácfa utca \\
\hline Postásköz & Bocskai utca \\
\hline Baliköz & - \\
\hline Alsó utca & Csók István utca \\
\hline $\begin{array}{l}\text { Roboz utca / } \\
\text { Lenin utca }\end{array}$ & Széchenyi István utca \\
\hline Húsbolt utca & - \\
\hline Violaköz & Violaköz \\
\hline Zsákutca & Malomköz \\
\hline $\begin{array}{l}\text { Tamásköz I } \\
\text { Kocsmaköz }\end{array}$ & Kaffka Margit utca \\
\hline Csillagi út & Vörösmarty utca \\
\hline $\begin{array}{l}\text { Sikkesköz I } \\
\text { Berényi köz }\end{array}$ & Dobó István utca \\
\hline Kaszaköz & Rákóczi Ferenc utca \\
\hline Selliköz & Móra Ferenc utca \\
\hline Temető-köz & Hunyadi utca \\
\hline
\end{tabular}

pülésrészi érzület, a helyi identitás erósítése lehet egyik alapja Cece népességmegtartó képessége növekedésének. Javasolt, hogy „kétnyelvứ” (hivatalos és helyi) utcanévtáblákat helyezzenek el, amelyeken a falurész neve is feltüntetésre kerül (pl. Központ, Alszeg, Rekotya etc.). A cecei utcanevek egy részét hivatalosan is át kell nevezni, hogy az utcanevek az utcában élt „híres emberekre” utaljanak, a Madarász testvérekre, Csók Istvánra, Illyés Gyulára, Strausz Adolfra. 


\section{KÖZPONT}

Cece „Achilles-sarka”, hogy gyakorlatilag nincs központja. A régi központ egy közlekedési csomóponttá vált, amely csak arra alkalmas, hogy az autósok minél gyorsabban áthajtsanak rajta. Az elmúlt évtizedek modernista szemléletú fejlesztései felemás sikerrel célozták egy új központ létrehozását. A bolt, a kocsma és az orvosi rendeló elköltöztetése miatt kiürült a régi fóutca, a nyolcvanas évek igénytelen épületei és a kedvezótlen közlekedéstervezés miatt azonban az új központ nem vált a település lelkévé. Az újabb magánerốs beruházások miatt nem az „új utca”, hanem a Földvári út közeli sarka lett egyfajta új központ, miközben a fớutca megórizte a maga spirituális és részben gazdasági jelentôségét: a Deák Ferenc utcán halad végig hagyományosan a halottas menet, a nászmenet, ott van a két templom, a Vasbolt, a posta, a húsbolt, vegyesbolt és a polgármesteri hivatal.

A cecei fótér és fóutca rehabilitálása elodázhatatlan. Az átmenó forgalom csökkentése rövid távon is megoldható a Németkéri út és Fehérköröszt utca fejlesztésével, a településen belüli egyirányú körforgalom bevezetésével, hosszabb távon azonban csak az elkerüló út jelenthet megoldást - amely egyúttal lehetóséget teremt az óstermelés és a házi árusítás továbbélésére.

A Talapa-kocsma rehabilitációja, homlokzati rekonstrukciója és a fótér sétálhatóvá tétele halaszthatatlan feladat. A fótérnek nevet kell adni, amely persze lehet a hagyományos Talapa-sarok elnevezés is. A Talapa-saroknak vissza kell kapnia régi hangulatát, azt a világot, amikor az azóta elbontott kocsma kerthelységében találkozhatott a falu apraja-nagyja. Összefüggó teret kell kialakítani a parktól (ma szovjet hốsi emlékmú) a Csók István-kastélyig és a katolikus templomig.

\section{ALKÖZPONTOK}

Míg a központ bóvelkedik identitásképzó helyekben, a többi falurész nem. Legkevesebb identitásképzó elemmel bír a Csillag utca és Sikkesköz vidéke, az Újtelep és a Németkéri út. Az önkormányzat helyi emléktábla-avatásokkal, valamilyen közfunkció kitelepítésével, idôvel egy-egy szobor vagy középület állításával tudja erósíteni a terület identitását.

Az egyes falurészekben segíteni kell helyi alközpontok kialakulását. Az alközpontokban kis bolt vagy presszó, alkalmi árusítóhely, árnyat vetó fák, padok, sétatérburkolat, szobor helyezendó el. 
Fejlesztendó alközpontnak javasolt:

- Fischer-sarok;

- Hốsi emlékmú és Hatósági húsbolt környéke (a térnek nevet kell adni!);

- Folyóskút és környéke;

- Temetó-tó környéke;

- Fehérköröszt utca / Földvári út sarok (ahol a fehér kereszt áll);

- Felvégen a Bogárdi / Fehérköröszt sarok;

- Alszegen az Alsó utca / Postás köz sarok.

\section{A Csók IsTVÁN-KÚRIA}

Csók István a Cece és Sárergres között álló malomban látta meg a napvilágot. Jómódú szüleinek köszönhetóen Münchenben és Párizsban tanult festészetet. A magyar impresszionista és posztimpresszionista festészet egyik kimagasló alakja. Több festménye (mint például az Úrvacsoraosztás) a szülóföld témáit eleveníti fel. Önéletrajzi könyve (Emlékezéseim. - Budapest: Officina, 1945; Akadémiai, 1988) leglíraibb részei a gyerekkori emlékek, melyekból a századfordulós Cece élete is kirajzolódik. A Csók család kastélya Cece kiemelkedó múemléke. Javaslat: Csók István emlékét a cecei Csók-napok (fesztivál) keretében kell emlékezetessé tenni. A fesztivál javasolt idópontja a nyári turistaszezon, tartalmát tekintve pedig a vizuális múvészetek kapjanak kiemelt szerepet, azaz legyen benne kézmúvészeti és festészeti alkotótábor, filmvetítés (a filmmúvészet valamilyen speciális ága), esténként etno-zenei hangulatteremtés. A fesztivál családi és fiataloknak szóló rendezvény legyen. A Csók-fesztivál keretében megvalósítható számos eredeti cecei javaslat:

- sör-dinnye verseny (ki tud több liter / vagy kiló sört vagy dinnyét elfogyasztani együltó helyében; szülók és gyerekek közösen mérkózhetnek);

- dinnyehéj-faragás és esti világító felvonulás;

- pörkölttorta verseny;

- Kovács László operatốriskola;

- Noé László fafaragókurzus;

- Lázár Ervin mesemondó verseny;

- „Szabad a Csók” bál, ahol - tinédzserbulik mintájára - zene közben 1-2 másodpercre leoltják a lámpát...

Elengedhetetlen a szülóház, azaz a malom rendbehozatala, panzióvá és ebédlóteremmé alakítása, lehetóleg magántóke részvételével. Számos közösségi eseménynek a Malom adhatna otthont. 


\section{Kovács Bence, Letenyei László és Szathmári Milán 2004: Telki mentális térképe*}

\section{Hogy LÁTJÁK TELKIT A TELKIEK?}

Az elmúlt hetekben sok emberrel beszélgettünk Telkiben. Legtöbb beszélgetópartnerünk örült annak, hogy Telkiben élhet. Nem csak a táj szépsége és az egészséges lakókörnyezet miatt szerették meg az ideköltözók Telkit, hanem mint sokan kiemelték, a jó szomszédság, a többi rokonszenves telki lakos miatt is.

Különös értéke Telkinek - és ez nincs így minden agglomerációs településen -, hogy itt jó a viszony a régebb óta itt élók („óslakosok”, a sváb és székely családok), illetve a régebben és újabban betelepülók között.

Érdekesség, hogy ez a három csoport mégis eltéróen látja magát a települést. A következókben néhány térképvázlatot mutatunk be.

Telki (Töllech) belterületének és határának egykori sváb elnevezései mára jórészt feledésbe merültek. Az itt éló néhány sváb család már nem emlékszik pontosan minden határrész, dúló régi sváb elnevezésére. A fennmaradt elnevezésekról viszont elmondhatjuk, hogy kiállta az idók próbáját. Egyes régi elnevezések, mint például a Boszorkányos liget (Hexenstutten). talán a sváb betelepítés elótti idók emléke.

A székely származású telkiek számára Telki mai belterülete még gyermekkoruk erdeit-mezóit jelentette. Számukra a „hivatalosan” Legelódombnak nevezett rész például Kakukkhegy, mert mint mesélték, ott vigyáztak nyári éjszakákon a telki határ felett, és onnan riasztottak (kakukkoltak), ha valaki dézsmálni akarta a termést.

A Telkibe 1990 óta költözók már egy másik Telkit ismertek meg és vettek birtokba. Az ó idejükben például a téesz felbomlása idején a telki határt évekig nem múvelték. A parlagföldeken tavasztól kezdve „annyi volt a pipacs, mint a tenger”. Az új központ beépítetlen részének telki neve még ma is a „pipacsos”.

Sajnos, az erószakos kitelepítéssel, a gyakran hibás privatizációval és az elkerülhetetlen környezeti rombolással sok régi hagyomány ment talán örökre veszendóbe. Reméljük nem örökre. Sajnálatos például, hogy az egykori Hexenstutten, a boszorkányos liget mai neve: 069-es. Pedig mennyi legenda, helyi történet kötốdhetett e névhez!

* TeTT Consult Kft. Telki Napló, 2004. 2. szám. 
Telki mentális térképe az ott élő sváb lakosság beszámolói alapján
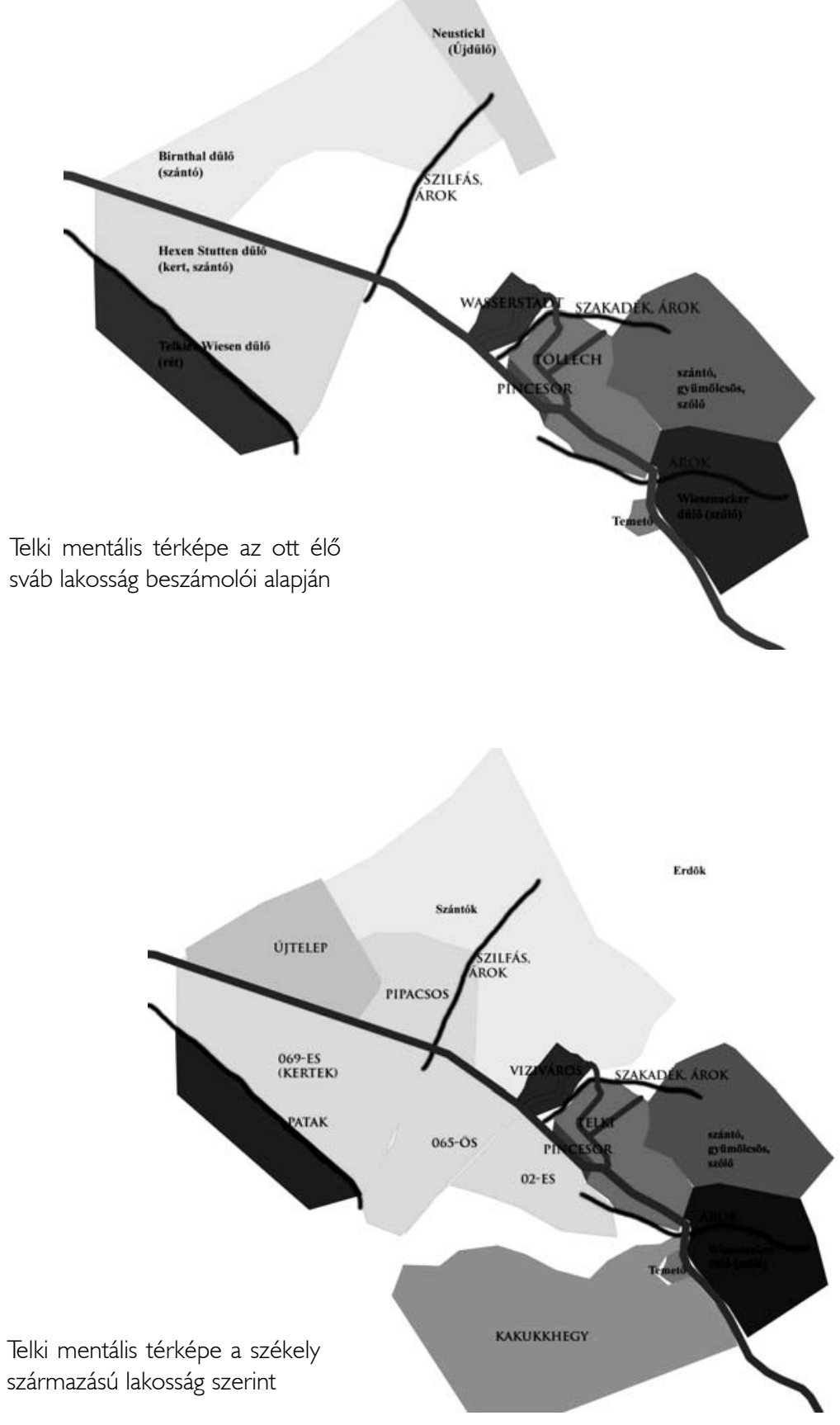

Telki mentális térképe a székely származású lakosság szerint

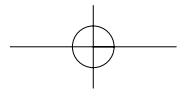


646 TELEPÜlÉSKUTATÁS - VI. MeNTÁlIS TÉRKÉP SZERKESZTÉSE

A privatizáció során a telki szólóhegy nem a telkiek tulajdonába került. Mivel telki embernek nemigen van saját bora, az ốsi (és nem utolsósorban: gyönyörúi) telki pincesor jelentốsége a telkiek számára elenyészó. Jól jelzi ezt a telkiek pincesor környékének mai neve: ez a rész a „kanyar”, illetve az „útszúkület”.

Az idók változását jelzó legszomorúbb változás a telki patak sorsa. Az egykori tiszta vizú patakban a mai ötvenévesek még kézzel fogták a rákot és táj jellegzetes apró halfajtáját, a kövi és réti csíkot. Bizony, az egykori telki patakból mára a budajenói szennyvízcsatorna lett. Hogy ez a búzös iszapcsík valaha tiszta vizú patak volt, azt már nemcsak az újonnan érkezók, hanem az itt éló mai harmincévesek is hitetlenkedve hallgatják: a források már a téesz-idókben eliszaposodtak. Szerencsére remélhetjük, hogy a szennyvíztisztító már tervezett bóvítése megteremti a lehetóséget a patak rehabilitációjára, hogy Telki újra a tiszta források földje legyen.

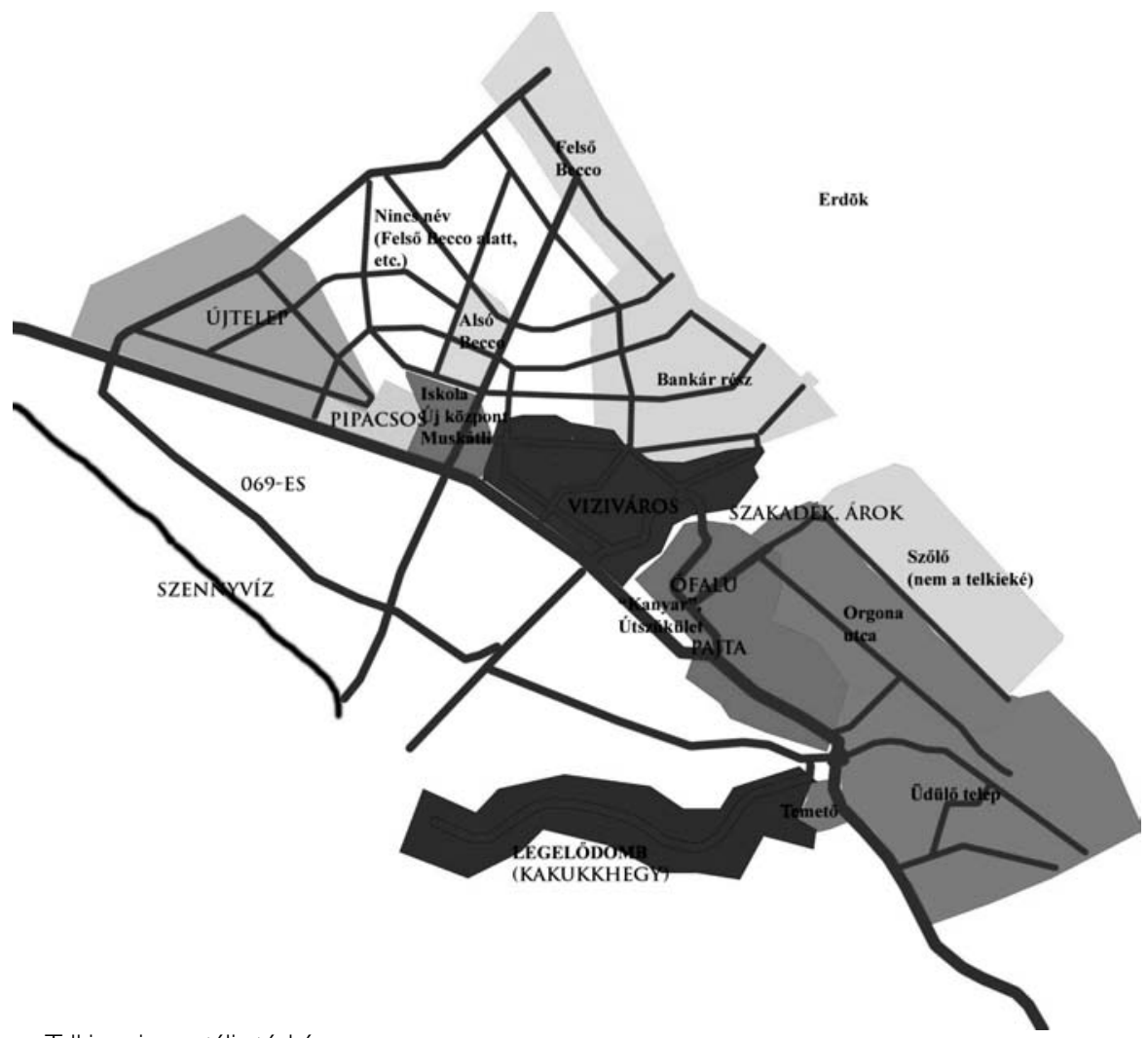

Telki mai mentális térképe

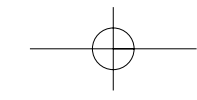

